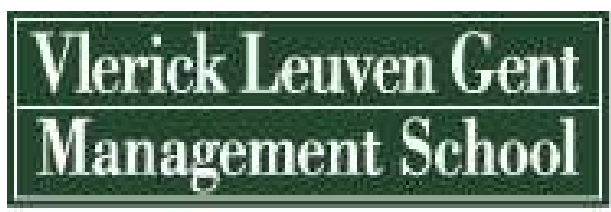

the Autooumuen Management Srhool of

Chesat Laiversity ued Katholinke Univeraiteit Istukn:

Vlerick Leuven Gent Working Paper Series 2005/1

\title{
PRIVATE EQUITY INVESTMENTS AND
}

\section{DISCLOSURE POLICY}

\author{
CHRISTOF BEUSELINCK \\ MARC DELOOF \\ SOPHIE MANIGART
}

Sophie.Manigart@ vlerick.be 


\section{PRIVATE EQUITY INVESTMENTS AND}

\section{DISCLOSURE POLICY}

\section{CHRISTOF BEUSELINCK}

Ghent University

MARC DELOOF

University of Antwerp

SOPHIE MANIGART

Vlerick Leuven Gent Managementschool

This paper has benefited from presentations at the XVII Annual Conference of the European Accounting Association (Prague), the Spring 2004 Accounting Research Day (Antwerp University) and the VIII Annual European Conference of the Financial Management Association (Zurich). We gratefully acknowledge helpful comments from Wouter De Maeseneire, Heidi Vander Bauwhede, Peter Wysocki as well as participants of the Doctoral Student Seminar of the European Financial Management Association (Basel).We also thank Katleen Baeyens for helpful assistance in the data collection. Financial support from the Fonds voor Wetenschappelijk Onderzoek (Grant $n^{\circ}$ G2000.12) is kindly appreciated. The usual disclaimer applies.

\section{Contact:}

Sophie Manigart

Vlerick Leuven Gent Management School

Tel: +32092109816

Fax: +32092109700

Email: Sophie.Manigart@vlerick.be 


\begin{abstract}
We investigate whether a firm's disclosure policy is affected by the changing corporate setting and intensified corporate governance associated with private equity (PE) investments. For a unique sample of unquoted PE backed firms we observe a significant switch to increased financial disclosure in the pre-investment year, consistent with the hypothesis that entrepreneurs attempt to reduce information asymmetries inherent to the PE application by increasing their disclosure levels. Further, we document that the governance and professionalization impact of PE investors affects their portfolio firms' financial disclosure positively. Finally, differentiating on investor type (government versus non-government related) reveals no overall effect on disclosure, both in the pre- as in the post-investment years. Results are robust to various sensitivity checks.
\end{abstract}

(JEL classification: G30, M10, M41)

Keywords: Disclosure, private equity, unlisted firms, monitoring, corporate governance. 


\section{INTRODUCTION}

Since decades, corporate decisions to disclose information to outsiders have been of interest for both analytical and empirical accounting researchers. This issue is of major importance as economic theory suggests that a firm's disclosure policy is negatively related to its cost of capital since disclosure reduces information asymmetries. Analytical studies have modeled the discretionary disclosure of information in various settings resulting in full disclosure (Grosman 1981, Milgrom 1981) and partial disclosure equilibria (Bhattacharya and Ritter (1983), Verecchia (1983), Diamond and Verecchia (1991), Gigler (1994)). Empirical work on corporate disclosure is rooted in the 1960s and typically examines the effect of increased levels of disclosure on a firm's ability to reduce agency costs. However, results of these studies are mixed. Other studies focus explicitly on the interaction between a firm's corporate governance structure and its disclosure policy. Again, results are mixed: authors find both positive and negative relations between the intensity of a firm's corporate governance structure and its disclosure policy.

The current study is situated in the latter stream of research, in that we study the impact of changes in ownership structure and corporate governance on a firm's disclosure policy. More specifically, we examine disclosure policies of a large hand-collected sample of Belgian unlisted firms receiving private equity (PE) financing from professional equity investment companies, both in the period before and after the PE investment. ${ }^{1}$ The motivation for using this dataset stems from the unique Belgian institutional and legal framework which requires all national companies (both listed and unlisted) to file yearly financial statements to the National Bank of Belgium. This offers a richness of financial statement information and provides the opportunity to study the effect of a change in ownership and governance structure resulting from the PE investment on a firm's disclosure policy, even when firms are not subject to stock exchange reporting requirements. Further, this dataset is unique in that it contains (changes in) firm-specific disclosure observations around a clearly identified PE financing event and thus allows to study corporate disclosure policies as a response to information-asymmetries and agency problems inherent to the PE offering. As such, this research takes into account that disclosure decisions are non-random events and responds to the worry of researchers that disclosure is often treated independently from a firm's changing environment or economics (Healy and Palepu (2001)).

A study like this is interesting for several reasons. Studies on unlisted firms is appealing in its own right, due to the predominance of private companies in the economy and 
the fact that only marginal attention has been paid to these kind of firms in empirical studies. ${ }^{2}$ Moreover, the PE setting is particularly interesting since it is characterized by various information asymmetries and agency problems which inherently affect the business process and organization. Therefore, the use of financial statement information is important in a PE context, even for unlisted firms (Hand (2005)). We acknowledge the importance of financial statement information and study the relation between the (nearby) governance of a PE investor and a firm's disclosure policy. Hereby, the current study not only complements accounting research on determinants of disclosure but also entrepreneurial finance research which often treats the corporate reporting environment as exogenous.

We argue that a firm discloses more information to the outside world when raising PE finance and derive this argument from basic economic theory. The information asymmetry problem that typically arises between a better-informed entrepreneur and outside PE investors gives rise to the lemons problem, which causes good and bad projects to be valued at an average level (Akerlof (1970)). In an attempt to resolve this problem, the best entrepreneurs signal their superior quality and increased disclosure might be a valuable instrument to do so. Various studies have shown that financial figures are key determinants in screening and selecting portfolio companies, especially in Continental Europe (MacMillan, Zemann and Subbanarasimha (1987); Fried and Hisrich (1994); Wright and Robbie (1998); Manigart et al. (2000)). Moreover, survey evidence shows that more than $70 \%$ of professional investors labels accounting disclosure as the most important item which impacts their investment decision (McKinsey (2002)). Consequently, we argue that high quality entrepreneurs showcase their financial reporting openness and professionalism to outsiders by increasing their disclosure levels. We therefore expect and also find evidence of increased disclosure of financial information in the year before firms get PE.

Second, we argue that portfolio firms' disclosure policies are affected by PE investors' governance. This argument originates from the well-illustrated phenomenon that PE investors are close monitors of their portfolio firms (Gompers (1995), Sapienza, Manigart and Vermeir (1996), Kaplan and Strömberg (2002)). These monitoring efforts are particularly driven by the agency problem, as described in Jensen and Meckling (1976), where the interests of principals (here: PE investors) and agents (here: entrepreneurs-managers) are not perfectly aligned. As a response to the agency problems, PE investors are intensively involved in their portfolio firms' day-to-day activities and contract a substantial number of controls like cash flow and control rights contingent upon observed performance measures (Gompers (1995), Robbie and 
Wright (1998), Gompers and Lerner (2001), Kaplan and Strömberg (2002)). This strong PE investor involvement results in a substantial change in governance and positively affects the professionalism the firm is operating with. We argue and show that this intensified governance and professionalization is noticeable in the way financial reporting is conducted and, as such, is manifested in a higher disclosure of financial information to outsiders.

To document these propositions empirically, we study disclosure policies of a large sample of unlisted Belgian PE backed firms from (at most) 3 years before until (at most) 5 years after they received PE for the first time in their history, and compare these with a matched sample of independent firms that never received PE. Since the firms under analysis are unlisted and press releases or extended annual reports are rare for these kind of firms, we gauge a firm's disclosure behavior by looking at its willingness to report complete (i.e. more detailed) financial statements when abbreviated (i.e. shorter in length, providing less detail) statements are sufficient to comply with legal requirements. Complete financial statements require more intensive preparation and financial expertise and contain more competitive information. Hence, complete financial statement disclosers incur substantially higher proprietary costs than firms which only report abbreviated financial statements. In the pre-PE financing period one would only expect firms to switch to a complete financial statement reporting if the increase in proprietary costs resulting from the increased disclosure is offset by the decrease in information asymmetry. After the PE investment it is likely that the financial expertise, the intensified monitoring and professionalism of the PE investor will be dominant, leading to expectations of a higher disclosure policy when professional PE investors become involved.

Through panel data analyses, we find that PE portfolio firms partly resolve the information asymmetry gap by disclosing significantly more financial statement information than they are legally obliged to, especially in the pre-PE financing year. These differences remain significant when we control for firm-specific characteristics and potential endogeneity problems. From the PE investment year onwards, PE backed firms are even more likely to disclose complete financial statements compared to both the matched sample and the preinvestment firm-years. This finding suggests a clear governance and professionalization impact of PE investors on their portfolio firms' disclosure behavior. Further, we condition for differences in investor type by splitting our sample in government PE backed and nongovernment PE backed firms. We expect that the lower monitoring and governance impact which is often associated with government-related PE investors will yield lower disclosure 
levels for their portfolio firms. Results, however, do not support this view although government PE backed firms switch earlier to a high disclosure strategy. This suggests that the well-documented difference in governance and professionalization between government and non-government PE investors has no sizeable effects on the way financial disclosure of their portfolio firms is enforced.

The current study has several contributions. First, this study distinguishes itself from the traditional disclosure literature which studies governance structures in relation to a firm's disclosure behavior. Prior studies typically associate proxies for a firm's governance structure with aggregate measures of disclosure tendencies (Raffournier (1995), Ho and Wong (2001), Eng and Mak (2003)). However, these studies face the problem of being short of good proxies for a firm's governance structure which often results into mixed results. The firms analyzed in the current study are unique in that they contain an indisputable change in governance system resulting from the PE involvement. This provides an exclusive setting to study the impact of intensified scrutiny and governance pressure on a firm's disclosure behavior. Second, prior studies typically investigate disclosure tendencies of publicly listed companies, primarily driven by data unavailability of unlisted firms. However, recent evidence shows that financial statement information matters for unlisted firms, especially in a PE context, and that this issue is surprisingly neglected in the literature (Hand (2005)). The current study acknowledges this shortcoming and enhances the understanding of the use of disclosure for unlisted firms in response to increased scrutiny and governance by PE investors. Third, most studies analyze disclosure behavior cross-sectionally and typically neglect intertemporal dependencies. However, disclosure decisions are non-random events and cannot be treated independently from a firm's changing environment or economics (Healy and Palepu (2001)). The current study overcomes this disregard and exploits the characteristics of a longitudinal dataset to analyze the disclosure evolution in a panel data context.

The paper proceeds as follows. Section 2 reviews the corporate disclosure literature. In section 3, we build hypotheses by combining the PE framework and the disclosure setting. In section 4, we describe the research setting, explore the characteristics of the Belgian PE industry and illustrate the sample properties. In section 5, detailed statistics are provided and section 6 reports the results of our multivariate analyses. Finally, section 7 concludes and discusses the results. 


\section{LITERATURE REVIEW}

Literature on disclosure, both analytical and empirical, is extensive and typically focuses on the interplay between information asymmetries and disclosure policy. Information asymmetries create costs by introducing adverse selection in transactions between economic agents (Akerlof (1970)). It is commonly accepted that a firm can reduce the level of information asymmetries by committing itself to disclose more information to the outside world. Analytical studies on disclosure policy have been pioneered by Grosman (1981) and Milgrom (1981). These studies find that economic agents are better off by adopting a full disclosure policy since incomplete disclosure results in buyers' suspicion and, as a consequence, high price discounts. Verecchia (1983) shows why real-life disclosure is often non-complete by introducing proprietary costs, i.e. costs associated with increased levels of disclosure originating from the preparation and presentation efforts and the higher exposure to competitors. Hence, economic agents are typically not willing to disclose all information they hold since this generates proprietary costs. While outsiders do not know to what extent the withheld information represents good or bad news, the value of the firm typically is lowered to a threshold level whereby a manager is motivated to withhold a specified amount of information.

A stream of empirical research focuses on the determinants of a firm's voluntary disclosure decision and the associated economic benefits of increased disclosure. These economic benefits are often valorized by studying the relation between a firm's cost of capital and its disclosure policy. To test this relation, researchers focus on various proxies for a firm's cost of equity capital like bid-ask spreads (Healy, Hutton and Palepu (1999), Leuz and Verecchia (2000)), stock liquidity (Botosan and Frost (1998), Leuz and Verecchia (2000)), share price variability (Leuz and Verecchia (2000)) and accounting-based valuations (Botosan (1997)). Botosan (1997) finds evidence that greater disclosure is associated with a lower cost of equity capital, but only for firms with low analyst following. Botosan and Frost (1998) find a positive association between stock liquidity and the timeliness of disclosure. Leuz and Verecchia (2000) show that German firms switching from German GAAP to IAS or US GAAP experience lower bid-ask spreads and higher trading volume but record no improvements with respect to share price variability. Sengupta (1998) analyzes a firm's cost of debt capital in relation to disclosure and finds that firms with timely and clear disclosures are rewarded with a lower cost of borrowing. 
Related studies use the context of equity offerings to investigate the interaction between a firm's disclosure policy and its associated cost of capital. Schrand and Verecchia (2002) study disclosure policies around Initial Public Offerings (IPOs) and find that greater disclosure frequency in the pre-IPO period is associated with lower underpricing. Marquardt and Wiedman (1998) find that prior to a Seasoned Equity Offering (SEO), firms often increase their disclosure level substantially to reduce information asymmetries inherent to the equity offering. Lang and Lundholm (2000) document that a consistently high disclosure strategy leads to a reduction of the information asymmetry inherent in the offering, whereas increased disclosure often is a result of an attempt to "hype the stock".

Other studies focus more explicitly on the governance-related determinants of a firm's disclosure behavior and analyze this behavior in an agency context where principals and agents have different objectives (Jensen and Meckling (1976)). Managerial ownership is seen as an indication of the alignment of interests between principals and agents resulting in studies investigating the relation between a firm's disclosure policy, its ownership structure and the corporate governance system in-place. Ruland, Tung and George (1990) find that ownership structure, measured as the percentage of voting stock owned by officers and directors, is by far the most important variable in explaining a firm's disclosure of earnings forecasts. Forker (1992) reports a positive association between the tightness of a firm's corporate governance system and share option disclosures. Ho and Wong (2001) study Hong Kong listed firms and document that the existence of an audit committee is positively related to the extent of disclosure while the percentage of family members on the board has a negative impact on disclosure. Eng and Mak (2003) study firms listed on the Singapore Stock Exchange and find a positive association between government ownership and voluntary disclosure, while both the number of outside directors and managerial ownership influence disclosure behavior negatively. However, Raffournier (1995) does not find a specific relation between the disclosure policy of Swiss firms and their ownership structure.

To our knowledge, no prior studies have explicitly considered the PE investment process and the associated disclosure policy of their portfolio companies. Gompers (1995), Lerner (1995) and Kaplan and Strömberg (2002) have studied the monitoring function of PE investors more in general. Others, like Hellmann and Puri (2002) focus on the supportive role of $\mathrm{PE}$ and find that $\mathrm{PE}$ is related to a number of professionalization measures like human resource policies, the adoption of stock option plans and hiring a marketing vice president. Mitchell, Reid and Terry (1995) show that PE investors have a substantial post-investment 
demand for accounting information and that accounting profit targets are often used as safeguards in bonding arrangements. None of the aforementioned studies, however, measures to what extent the PE investment process impacts the portfolio firms financial reporting practice. We argue that applying for and receiving PE affects a firm's business environment and study how the disclosure issue is related to this.

\section{HYPOTHESES DEVELOPMENT}

$\mathrm{PE}$ is a financing alternative for entrepreneurial firms when traditional financing mechanisms like bank loans and other credits are difficult or even impossible to obtain. As such, PE has developed as an important intermediary in financial markets and is especially appropriate for the financing of firms where large information asymmetries and agency problems are present (Admati and Pfleiderer (1994), Gompers and Lerner (2001)). In this section, we argue how both aforementioned issues are thought to impact the corporate disclosure behavior of portfolio firms in the years around the PE financing.

\section{Disclosure and Pre-Financing Information Asymmetries}

Anecdotal evidence and academic studies show that PE investors screen potential entrepreneurial companies extensively before deciding to invest in the company. Selection only takes place when a firm successfully passes an initial screening round and a more thorough due diligence process (Robbie and Wright (1998)). Although there are substantial differences across firm types, industry and geographic location there is anecdotal evidence that out of 100 proposals that are submitted to a PE investor per year, on average only ten pass the initial screening round and from these ten, only one or two actually receive PE financing (Berlin (1998)).

Since information asymmetries and adverse selection problems clearly determine the probability of receiving PE financing, good entrepreneurs have an incentive to signal their high quality to outside PE investors. One option for entrepreneurs to signal their dedication is retaining a substantial equity stake in the venture firm (e.g. Leland and Pyle (1977)). This behavior mitigates the agency conflict by aligning the interests of entrepreneurs and outside investors. Other important criteria on which PE investors ground their investment decisions are viability and novelty of the project, financial profitability, skills and dedication of the entrepreneurial team and possibility for high returns at the exit time (Hall and Hofer (1993) 
Fried and Hisrich (1994), Robbie and Wright (1998)). It is of paramount importance that entrepreneurs who want to attract PE score sufficiently high on most of these criteria to signal their high quality to potential investors.

Evidence further shows that accounting information is a crucial issue which is required by PE investors before deciding to invest (Manigart et al. (2000), Kaplan and Strömberg (2004)). In general, professional investors rate accounting disclosure as the most important element which impacts their financing decision (McKinsey (2002)). Given that the use of accounting information and its disclosure extent is highly important in screening and selecting investment opportunities, we expect entrepreneurs to give more attention to it when applying for PE. Entrepreneurs can reduce information asymmetries inherent to the PE offering by disclosing more information than legally required to outside stakeholders. From an investor's point of view, a high disclosure strategy is likely to be evaluated positively since this behavior not only indicates a high professionalism with respect to the in-house financial reporting process but also a readiness to disclose information after the PE investment has taken place. We therefore postulate that high quality firms switch to a higher disclosure level prior the PE investment in an attempt to reduce information asymmetries and to signal their superior quality.

In the line of this reasoning, we postulate that a high disclosure strategy will initially facilitate the PE financing search through a reduction of the information asymmetry present in the first steps of the quest for PE. Entrepreneurial research generally agrees that PE investors have access to internal documents which generally contain substantially more information than the published annual report (e.g. Fried and Hisrich (1994), Robbie and Wright (1998)). At first sight, this would mean that increased disclosure would not have additional value to PE investors, since they have in-depth information which goes beyond the disclosure of financial information. However, we argue that entrepreneurial firms catch the attention of PE investors, amongst others, by increased disclosure levels. At the time entrepreneurs start their search for financing, PE investors do not yet posses the detailed information they typically ask for in the due diligence process. Hence, a high disclosure strategy is a valuable tool to reduce initial information asymmetries in the search for PE.

\section{Disclosure and Post-Financing Monitoring}

Whereas the pre-investment period is typically dominated by information asymmetries and adverse selection problems, the mutual relationship which arises between the 
entrepreneur and its PE investor after the PE investment is subject to potential agency conflicts and moral hazard problems. There is substantial evidence that PE investors address agency conflicts by extensive monitoring ex post, which typically intensifies the portfolio companies' corporate governance system in-place (e.g. Gompers (1995), Lerner (1995), Robbie and Wright (1998), Gompers and Lerner (2001), Kaplan and Strömberg (2002)). Hellmann and Puri (2002) go beyond this monitoring role of PE and find that PE investors play a supportive role in building the entrepreneurial firm.

We argue that the intensified monitoring and professionalization originating from the PE investor will affect the disclosure policy of portfolio firms. Since PE investors play a role that goes beyond that of traditional financial intermediaries, it is likely that they guide and professionalize the financial reporting process. Since PE investors typically monitor their portfolio companies closely, they may contract deals with their portfolio firms stipulating that the financial reporting should comply with some minimum reporting criteria, like e.g. have a substantial amount of public disclosure. Further, portfolio companies also benefit from the financial expertise and in-house knowledge of the professional PE investor enabling them to report complete financial statements with a minimum of effort. Thus, professionalization is another factor which is expected to drive disclosure positively. Both arguments suggest that PE backed firms are likely to disclose more information than would be the case without PE involvement. As such, we postulate that from the PE investment onwards, PE investors' involvement evokes a higher disclosure policy.

Taking the aforementioned elements into account, we incline towards the argument that PE governance and portfolio firm's disclosure are complements rather than substitutes. Consistent with the complementary argument of intensified corporate governance, we associate a greater extent of disclosure with additional PE monitoring since the adoption of more governance mechanisms strengthens the internal controls in order to minimize opportunistic behavior and information asymmetries (Leftwich, Watts and Zimmerman (1981)). Alternatively, PE monitoring could also be a substitute for voluntary disclosure since higher monitoring influence could reduce the need for other governance mechanisms, such as higher disclosure levels. PE investors, however, are concerned about their perceived quality in the PE industry (Gompers and Lerner (2001)). Provided that PE quality is generally reflected by the quality of their portfolio companies, it is likely that PE investors use their monitoring power to implement a high disclosure policy in their portfolio companies. 


\section{Disclosure and Investor Type}

Different types of PE investors often generate different types of deals, particularly because both the professionalism of the screening and monitoring activities are determined by investor type (e.g. Lerner (1999), Leleux and Surlemont (2003)). Since a firm's disclosure behavior is likely to be associated with the extent and intensity of its screening and monitoring efforts, one can question whether the disclosure policy of PE portfolio companies is affected by its investor type. Especially, we are interested in disclosure policies of firms backed by government-related PE investors versus non-government-related PE investors.

Managers of government-related PE investment companies are often labeled as civil servants and as such may not have the experience nor the motivation to select or support entrepreneurial companies (Manigart, Baeyens and Van Hyfte (2002), Leleux and Surlemont (2003)). Government-related PE investors' investment decisions are often driven more by a societal goal instead of a profit maximization standpoint (Lerner, 1999). Moreover, government-related PE investors have less pressure to earn a return on their investment, as they do not have to raise new funds from the market and may have other goals than value maximization for their shareholders (Gompers and Lerner (2001)). Further, the absence of performance-related incentive schemes in government-related PE investors create less incentives to monitor portfolio companies tightly compared to the profit-oriented incentive packages which are more commonly used in non-government PE investment firms (Leleux and Surlemont (2003)).

Provided that government-related PE investors use less stringent screening devices before the PE investment, are weaker monitors ex post and have less professional in-house skills to support their portfolio companies, we expect lower disclosure in government-PE backed firms compared to non-government PE backed firms and this both in the pre- and post-investment stage. Prior to the PE investment, firms which focus on attracting government $\mathrm{PE}$ and are aware of the lower professionalism and other goals of these government PE firms have less incentives to disclose additional information on top of the regulatory minima. ${ }^{3}$ From an investor perspective, firms with low disclosure levels may reflect a lower professionalism and/or a lower willingness to share information to outside PE investors making it more difficult for them to raise capital from more stringent and selective non-government PE instances. In the post-investment period, we expect the weaker monitoring activities in-place to result in a lower disclosure policy for government-PE backed firms compared to their nongovernment PE backed counterparts. ${ }^{4}$ 


\section{RESEARCH SETTING AND SAMPLE PROPERTIES}

To test the hypotheses, we use a unique hand-collected database containing financial statement information of Belgian companies that received PE financing between 1985 and 1999. This dataset has two major advantages which make it particularly attractive to study the disclosure issue.

First, all Belgian companies (both listed and non-listed) are obliged to deposit their financial statement annually at the National Bank of Belgium in accordance with Belgian Legislation. Hence, this dataset offers the opportunity to study the evolution in the disclosure behavior of unlisted firms which experience a clearly identifiable change in ownership and governance structure resulting from the PE investment. Such a dataset is typically not available in a classical research context like the US where detailed financial statement information of unlisted firms is not retrievable. Therefore, this dataset offers an excellent opportunity to study disclosure behavior of unlisted firms as a response to $(i)$ increased scrutiny by outside PE investors before the investment date and (ii) a changing corporate governance and increased professionalization ex post. Although unlisted firms, on average, experience a lower demand for high quality financial accounting compared to listed firms and are less subject to public scrutiny, their disclosure decision may nevertheless be affected by the decision to raise PE financing and the change in governance and professionalization ex post.

Second, the Belgian PE industry differs substantially from that in the US and the UK and even other Continental European countries since approximately half of all PE investments come from government-related PE firms (EVCA, various yearbooks). Hence, our specific dataset on Belgian PE deals may provide useful insights in whether differences in PE investor types and characteristics (i.e. government versus non-government related) affect the disclosure policy of their portfolio firms.

\section{The Belgian PE Industry}

Before the 1980s, Europe and the US were two different continents with respect to PE financing patterns. The absence of a supportive entrepreneurial spirit across Europe combined with poor exit alternatives offered by the stock market resulted in a substantial underdevelopment of the European PE industry compared to the US. The Belgian situation 
was comparable to the one in Europe, where PE only gained importance after the 1980s. Evidence of this juvenile character of the Belgian PE industry is clearly illustrated when comparing the importance of the industry with respect to the size of the economy. During our observation period 1985-1999, average Belgian PE investments totaled 0.06\% of GDP. US figures are substantially higher, reaching values of 3 to 4 times that size during the same period (Manigart, Baeyens and Van Hyfte (2002)). Consistent with worldwide tendencies, the Belgian PE industry grew sharply, especially during the late 1990's bubble years to a maximum of $0.22 \%$ of GDP in 2000. Over the last two years, again following worldwide tendencies, total PE investments nearly halved to 0.12\% of GDP in 2002 (EVCA, various yearbooks).

During the observation period, the vast majority (58\%) of Belgian PE funds was invested in the expansion stage. Seed and start-up investments, replacement capital and buyouts accounted for respectively $26 \%, 9 \%$ and $7 \%$. The most popular investment sector was high-tech related (47\%), according to EVCA definitions, "communications, computer and other electronics related, biotech and medical or health related". Industrial-related and consumer-related sectors accounted for respectively $17 \%$ and $10 \%$ of all investments during that period.

With respect to investor type, the Belgian PE industry is further characterized by a large number of small independent PE investors and a few large PE investment houses (EVCA, various years). It is noteworthy that more than half of all PE investments made during our observation period come from government-related PE investors. Both the Flemish GIMV (Gewestelijke InvesteringsMaatschappij voor Vlaanderen) and the Walloon SRIW (Société Régionale d'Investissement de Wallonie) account for a substantial part of these government-related PE investments. Independent and captive investors both account for a mere $25 \%$ of total investments.

\section{Reporting Requirements of Belgian Firms}

Belgian companies are obliged to file their financial statement annually in compliance with Belgian Legislation. In accordance with the Royal Decree of October 8, 1976, small and medium-sized firms are allowed to report an abbreviated (i.e. less detailed) financial statement whereas large firms are obliged to report a complete (i.e. more detailed) financial statement. One of the main advantages of reporting an abbreviated format is its confined preparation time and the fact that it allows firms to protect potentially sensitive information 
from public scrutiny. Firms can only opt for the abbreviated format if they do not exceed two or more of the following criteria: $(i)$ annual turnover $<6,250,000$ euro, (ii) total assets < 3,125,000 euro and (iii) average number of full time employees < 50. If a firm employs more than 100 full time employees on an annual basis it is automatically classified as a large firm, irrespective of its sales or total assets level. ${ }^{5}$ However, small or medium-sized firms are free to supply more information than legally required by reporting a complete, i.e. more detailed, financial statement on a voluntary basis.

Complete financial statements differ from abbreviated statements in that they provide more detailed information on a number of financial statement items. With respect to the balance sheet, abbreviated formats provide less detail with respect to financial fixed assets, inventory and contracts in progress, investments and long term debt. The income statement also differs substantially since far less detail is provided on operating costs and expenses; these are summarized together with sales in a gross margin. Further, providing details on sales, purchases of raw materials, services and other goods is optional. Finally, accompanying notes to the financial statement are also restricted to a minimum for abbreviated formats.

\section{Disclosure Proxy}

The proxy used in the current study to measure a firm's disclosure policy is a selfconstructed measure related to the disclosure of financial statement items. Firms which comply with the minimum requirements to file an abbreviated financial statement but which nevertheless decide to disclose a complete financial statement optionally are labeled as highdisclosure firms. The motivation for using this disclosure proxy is that we analyze disclosure behavior of non-US based and unlisted firms. This restricts us from making use of standard disclosure measures like AIMR metrics or management forecasts. The metric used in this study is primarily related to the disclosure of financial statement information since alternative measures for disclosures like analyst meetings, conference calls and other professional venues are not applicable for this sample of unlisted firms. Although financial disclosure captures only one aspect of a firm's total disclosure behavior, we are convinced that this disclosure metric is relevant for our research context. Financial statements are one of the most important means by which unlisted firms communicate their business to the outside stakeholders. Moreover, studying financial accounting disclosure is particularly interesting since evidence shows that accounting disclosure is by far the most important issue for professional investors to ground their investment decision. Finally, other metrics for firm disclosure as well as 
management forecasts and AIMR disclosure scores have also been criticized in that they are evenly unable to capture a firm's total willingness to disclose and are often biased (e.g. Healy and Palepu, 2001).

Since abbreviated financial statements contain far less detail than complete financial statements, external parties are better informed about the firm's underlying business activities and the competitive situation of complete financial statement disclosers. As a result, SME firms that are legally allowed to issue an abbreviated financial statement but which, nevertheless, decide to issue a complete financial statement opt to provide a substantial amount of extra information to outside stakeholders. In the vein of Verecchia's (1983) arguments, we state that firms which report complete financial statements optionally, burden themselves with a substantial proprietary cost since they not only face higher preparation and presentation costs but also because they provide a substantially higher amount of firm details to outsiders which might harm their competitive position. Therefore, SME firms are thought to disclose complete financial statements based on the trade-off between the increase in proprietary costs and the intrinsic benefits inherent to this improved disclosure. Given that firms which are seeking for outside PE financing are typically cash constrained, we expect a higher willingness to disclose additional financial statement information, even if this disclosure is harmful for their competitive position. ${ }^{6}$

A concern, often overlooked in disclosure studies, is whether the disclosure act is a commitment to a higher disclosure policy rather than an ad hoc decision to disclose, which might be reversed if a firm feels the need to do so (Diamond and Verecchia (1991), Leuz and Verecchia (2000)). A commitment to a higher disclosure level yields higher economic benefits than a conditional disclosure decision since a consistently high disclosure policy has more information content. A firm's decision to disclose a complete financial statement generates switches in a firm's accounting system but could be reversed at a later time. However, we are convinced that by adopting a more complex and elaborated financial reporting strategy, firms build substantial financial expertise and know-how which is not likely to be reversed. Consequently, we expect and also find that this switch to a higher disclosure strategy causes a change in the firm's financial reporting attitude and professionalism and is a valuable proxy for a firm's disclosure commitment. ${ }^{7}$ 


\section{DATA AND DESCRIPTIVES}

\section{The Sample}

All analyses are run on a hand-collected database with financial and non-financial data of Belgian PE backed companies that received PE financing for the first time in their history over the period 1985 to 1999 . Deals were identified by consulting PE investment reports and press releases, while financial statements of the sample firms were retrieved from the financial statement information database of the National Bank of Belgium and 'Belfirst' $®$, a Bureau Van Dijk database. Next to the financial statements, we identified the PE investor identity and the exact date of the initial PE investment. To be included in this sample, portfolio companies have to be independent firms of which the financial statements are recorded on a regular basis in the database of the National Bank of Belgium. Further, financial and holding companies are excluded because of their highly specific nature and their industry-specific reporting requirements. This selection procedure results in a sample of 556 PE backed firms, representing nearly $40 \%$ of all PE investments in Belgium over the observed period.

To provide a basis for comparison, we selected a comparable sample of companies that did not receive PE, a method consistent with related studies in the field. Following Megginson and Weiss (1991), Jain and Kini (1995) and Lerner (1999), each PE backed company is matched as closely as possible with a non-PE backed independent firm on three criteria in the pre-investment year: (i) activity - measured by a two digit sector code -, (ii) size - proxied by total assets - and (iii) age. ${ }^{8}$ For firms which received PE funding in the start-up year, the matching year was set equal to the first year in which the financial statement data become available, typically being the investment year.

We focus on a sample firms' disclosure policies in the years around the PE financing event. These are the years of interest to study the effect of signaling, increased monitoring and changing professionalization on the portfolio firm's disclosure policy. We therefore focus our analyses on a time window of 3 years before until 5 years after the PE financing year. Since not all firms have information available from $(t-3)$, e.g. because they were not operational at that time, and not all firms report information until $(t+5)$ since firms can go bankrupt or merge with another firm, the sample is an unbalanced panel with maximally 9 years of consecutive data for each firm. 
To test our hypotheses, we concentrate on those firm-years in which firms comply with the requirements to report an abbreviated financial statement but are nevertheless free to provide a complete financial statement optionally. If a company discloses a complete financial statement although legally an abbreviated format is sufficient, it is labeled as a high disclosure firm since this firm is willing to carry the costs stemming from the increased disclosure in exchange for the alleged economic benefits. Hence, we leave out all firm-years from the initial dataset for which companies exceed the minimum requirements and consequently are legally obliged to report a complete financial statement, since these are not the focus of our research. This results in a substantial reduction in the number of observations in the analysis. E.g. in the year of PE financing, we find that approximately $33 \%$ of the initially identified PE firms exceed the legal requirements to report an abbreviated financial statement. Panel A of Table 1 shows a breakdown for the PE financing year on the number of available firm-observations in our PE backed and matched sample. Panel B additionally provides descriptive statistics on sample and matched firms' in the PE financing year.

Insert Table 1 About Here

Table 1 shows a breakdown of the available firm-observations both for the PE backed and non-PE backed matched sample. We summarize the results of our search in the PE financing year in Panel A. From the initially detected PE backed and matched sample, we have financial statement information of 876 firms (438 PE backed and 438 non-PE backed matched firms). ${ }^{9}$ Missing variables with respect to one or more of the reported minimum criteria limits us to 745 firms for which we can calculate whether a firm is allowed to report an abbreviated financial statement or whether firms are legally obliged to report a complete financial statement. Of these 745 firms, 336 are PE backed and 409 are non-PE backed. For 302 firms (146 PE backed and 156 non-PE backed), firm characteristics exceed two or more of the minimum requirements in the year of interest. Hence, these firms are obliged to report a complete financial statement, which makes that only 443 firms (190 PE backed and 253 nonPE backed) are, according to the law, allowed to report an abbreviated format. We focus our analyses on these firm observations since these are the firms that have the option to freely commit to a higher disclosure policy. We have calculated and computed the number of available observations in each firm-year in an identical way, leading to a variable number of observations across all years, in each sample. 
Panel B shows that in the year of PE-financing, sample and control firms are on average 9.60 years old, whereas the median age is 6.00 years. Mean (median) total assets are 1,557,752 $(1,014,479)$ EUR. Top three sectors are (1) computer related services $(22.3 \%),(2)$ wholesale distribution (19.4\%) and (3) building services (7.7\%). Testing the differences in means (medians) between both the PE backed and the non-PE backed sample shows that in the year of PE financing, both sets are similar with respect to age and sector distribution but that PE backed firms are on average larger than non-PE backed firms. ${ }^{10}$ Moreover, we find that the mean leverage is $67.6 \%$ and does not differ significantly between PE backed and matched firms. By contrast, PE backed firms are less profitable and have more fixed assets at their disposal than non-PE backed matched firms, and this both in a significant way.

\section{Variable Selection}

In what follows, we describe the variables used in the analyses and the way they are defined and collated. We identify variables that are related to the PE investment and its associated change in corporate governance next to additional firm-specific determinants of corporate disclosures which are often identified in the extant literature. The variable of interest, HIGHDISC, is a binary variable taking a value of 1 when a firm discloses a complete financial statement although legally an abbreviated format is sufficient. PE is a binary variable taking the value of one if a firm receives $\mathrm{PE}$ and is activated both in the pre- and post-investment years. $\mathrm{PE}_{\text {post }}$ is an interaction variable which is equal to one for PE backed firms, but only from the moment the firm receives PE financing and is zero otherwise. This variable measures the additional impact of PE investor's monitoring pressure on the firm's compliance to disclose complete financial statements. $\mathrm{PE}_{\mathrm{year}-3}$ and $\mathrm{PE}_{\mathrm{year}-2}$ are interaction variables used in the multivariate analyses. These variables are activated for PE backed firms three and two years prior to PE financing, respectively. Combinations of the interaction variables $\mathrm{PE}, \mathrm{PE}_{\mathrm{year}-3}, \mathrm{PE}_{\mathrm{year}-2}$ and $\mathrm{PE}_{\text {post }}$ allows to disentangle the differences in firms' willingness to disclose, both in the pre- and post-investment years, dependent on the incidence of being PE backed. GOVERNMENT is a dummy variable that is activated when a PE portfolio firm is backed by a government-related instance. We multiply this variable with $\mathrm{PE}$ and $\mathrm{PE}_{\mathrm{post}}$ to measure differences in firms' disclosure policy - again both in the pre- and post PE financing period - depending on PE investor type (i.e. government versus nongovernment related PE investors). All the aforementioned variables allow us to untie the impact of $(i)$ the entrepreneurial attempts to catch potential PE investors' attention by means 
of increased public disclosure in the pre-financing period and (ii) the monitoring and professionalization effect PE investors have on their portfolio firms' disclosure policy once these have invested.

We further incorporate firm-specific variables, previously identified as determinants of corporate disclosure behavior. LNAGE is the natural logarithm of a firm's age and is expected to be negatively related to a firm's decision to disclose (Raffournier (1995), Ho and Wong (2001)) since information asymmetries are typically higher in younger firms and might call for a higher disclosure extent. LEVERAGE is defined as (Total Liabilities/Total Assets) and quantifies a firm's solvency situation: a high leverage corresponds to having larger volumes of outstanding liabilities. High leverage levels are expected to substitute the need for additional disclosure since leverage helps controlling the free cash flow problem and the agency costs of debt are typically controlled through restrictive debt covenants rather than increased disclosure of information in annual reports (Jensen (1986)). FIXASSETS measures the proportion of a firm's fixed assets to total assets. Consistent with previous studies (Leftwich, Watts and Zimmerman (1981), Ho and Wong (2001)), we expect FIXASSETS to be negatively related to the voluntary disclosure proxy. A higher proportion of fixed assets is associated with less information asymmetry and consequently with a lower risk profile. XORDINC is a dummy variable taking the value of 1 when a firm's extraordinary income is higher than $25 \%$ of its current income level. Firms with a high extraordinary component in reported income are associated with more uncertainty calling for a positive association between XORDINC and HIGHDISC. Moreover, extraordinary items often impact the balance sheet and as such might also require a more detailed balance sheet (Chen, DeFond and Park (2002)). ${ }^{11}$ Finally, LOSS is a dummy variable taking the value of 1 when a firm reports a loss. Loss-making firms are potentially more risky than profitable firms and are as such potentially more compelled to disclose complete financial statements above the regulatory minima. Table 2 summarizes the definition and measurement of all variables used in the analyses and their expected relation with our disclosure variable. ${ }^{12}$

Insert Table 2 About Here 


\begin{abstract}
ANALYSES
Univariate Results

Table 3 shows a breakdown of the total number of firm observations available in each year around the PE financing event as well as the absolute and relative number of high disclosure firm-year observations. The proportional evolution of high disclosure firms within the PE backed sample and the matched sample is further illustrated in Figure 1.
\end{abstract}

\title{
Insert Table 3 and Figure 1 About Here
}

The number of available firm-year observations varies between a minimum of 128 (115) and a maximum of 285 (234) in the non-PE backed sample (PE backed sample). The total number of observations increases over time and reaches a maximum two years after the PE financing in both subsamples. This is due to the average age of the analyzed firms: a breakdown of the sample firms' age shows that about one third of the firms are younger than 2 years at the time of PE financing leading to an underrepresentation of firm-years in the prePE financing years compared to post-years.

In the non-PE backed sample, the average number of high disclosers remains constant over the observation period, exactly as we expected. On average, $14.9 \%$ of all non-PE backed firms disclose more information than legally required. By contrast the mean proportion of high disclosure firms in the PE backed sample is $27.6 \%$ and is significantly higher $\left(\chi^{2}=5.99\right)$ than the percentage within the non-PE backed sample. For the PE sample firms, the average percentage of high disclosers in the period before the PE financing date differs significantly $\left(\chi^{2}=4.41\right)$ from the percentage in the post-financing period: $17.3 \%$ versus $31.3 \%$.

The proportional differences per year across both samples show interesting patterns. Whereas the percentage of high disclosures for PE backed firms rises from $15.7 \%$ in $(t-3)$ over $23.7 \%$ in the year of PE financing to a maximum of $36.6 \%$ in year $(t+5)$, the proportion in the non-PE sample remains fairly stable around its mean level (14.9\%). Univariate test statistics show that the average proportion of high disclosers is significantly higher for the PE backed subsample than for the matched sample one year before the PE financing (at the $90 \%$ confidence level) and intensifies further from the PE financing year onwards. These univariate results indicate that (i) PE backed firms switch to a higher disclosure level in the pre-PE financing year and (ii) PE investors' involvement further impacts the disclosure policy of 
their portfolio companies positively. Conditioning the sample for government versus nongovernment PE backed portfolio firms shows no significant differences, suggesting no systematic impact of investor type on PE investors' disclosure policy at this level. ${ }^{13}$

However, these findings have to be interpreted with the necessary caution because they do not control for differences in firm characteristics. Table 4 shows descriptive statistics for the variables of interest in our total sample. Panel A reports cross-tables and $\chi^{2}$-statistics for high and low disclosure firms differentiating on (i) being PE backed, (ii) reporting a substantial extraordinary income (above $25 \%$ of current profit) and (iii) reporting a loss. In contrast to our expectations, high disclosure firms are proportionally underrepresented in the sample with high levels of extraordinary income. Differentiating for firms reporting losses versus profits does not yield significantly different patterns between the high and low disclosure subsample.

Panel B provides descriptive statistics on the continuous variables of interest and $t$-test and Mann-Whitney test statistics indicating the difference in means (medians) between high disclosure versus low disclosure firms. Results show that younger firms tend to disclose more, a finding in line with the postulation that younger firms are more risky and as such are more inclined to reduce information asymmetry problems by increased disclosure. Further, high disclosure firms have a significantly lower leverage compared to low disclosure firms, a finding consistent with the Jensen-type (1986) argument. We do not find significant differences in fixed assets between high and low disclosure firms.

Finally, Panel C of Table 3 presents Pearson and Spearman correlations between the variable of interest (HIGHDISC) and the continuous explanatory variables. All relations between HIGHDISC and the other variables are in line with the above results. Further, correlations between the independent variables are often significant but fairly small and suggest no collinearity problems in the multivariate analyses.

\section{Insert Table 4 About Here}

\section{Disclosure Model and Multivariate Results}

In this section, we apply pooled panel logit regressions to examine the dynamic relationship between a firm's disclosure policy, the change in corporate governance and 
professionalism driven by PE investors' presence, together with other firm-specific characteristics. To digress briefly on this methodology, panel data techniques combine crosssectional and time-series characteristics in an optimal model and control for individual heterogeneity across firms, collinearity among the variables and firms dynamics over time (Baltagi (2001)). Further, panel data analyses allow to capture firms' economics of adjustment to a specific state - here: disclosure policy - and suffer less from biases resulting from aggregation (Greene (1997), Baltagi (2001)). Given the binary structure of our dependent variable, a panel logit is the most appropriate method of analysis.

We model a firm's decisions to disclose as a function of receiving PE, both in the preand post-financing years, together with other cross-sectional determinants identified in the extant disclosure literature and also described above. Our initial panel logit model has the following form:

$H_{I G H D I S C}{ }_{i t}=\alpha+\beta_{1 i t} \cdot P E+\beta_{2 i t} . P E_{p o s t}+\gamma_{i t} . C O N T R O L$ VARIABLES $+U_{i t}$

We model to what extent a firm's decision to disclose complete financial statements is related to receiving PE financing and condition our analyses for pre-financing years $\left(\beta_{l}\right)$ and post-financing years $\left(\beta_{1}+\beta_{2}\right)$. Further, we incorporate control variables which we described above (Table 2). Results of this panel logit are reported in the first column of Table 5.

Insert Table 5 About Here

Results show clear evidence in line with the findings of the bivariate analyses. In the pre-financing years, PE backed firms have a significantly higher probability of being a high disclosure firm $\left(\beta_{l}=1.24\right)$. This probability increases strongly from the PE financing year onwards as $\beta_{2}=2.28$, leading to a compound coefficient in the post-PE financing years compared to non-PE backed firm-years of 3.52. These coefficients indicate that, prior to the PE financing, PE backed firms have about 21\% higher likelihood of being a high disclosure firm compared to non-PE backed matches, and an additional $67 \%$ increase in probability once the PE financing has taken place. ${ }^{14}$ Further, we find that both younger firms and low-leverage firms have a higher probability of being in the high disclosure sample. Both findings are in line with our expectations and the bivariate results. None of the other control variables are significant. 
Since we are particularly interested in the difference in disclosure policy between PE backed and non-PE backed firms very close to the PE-financing date, we additionally incorporate two year dummies $\left(\mathrm{PE}_{\text {year-3 }}\right.$ and $\left.\mathrm{PE}_{\text {year-2}}\right)$ in our model. Including these dummies allows to distinguish differences in disclosure behavior between PE backed and non-PE backed firms one year before the PE financing compared to earlier pre-financing years and compared to post-financing years. Model (2) shows this relation:

$$
\begin{aligned}
\text {HIGHDISC }_{i t}= & \alpha+\beta_{1 i t} . P E+\beta_{2 i t} . P E_{\text {year }-3}+\beta_{3 i t} . P E_{\text {year }-2}+\beta_{4 i t} . P E_{\text {post }}+\gamma_{i t} . \text { CONTROL } \\
& \text { VARIABLES }+U_{i t}
\end{aligned}
$$

The results of the second column of Table 4 show the significantly higher tendency to report complete financial statements one year prior to the PE financing $\left(\beta_{l}=1.92\right)$. We find no relation between a firm's disclosure policy and being three or two years before its PE financing date: as well $\left(\beta_{1}+\beta_{2}\right)$ and $\left(\beta_{1}+\beta_{3}\right)$ are insignificantly different from zero. Further, the additional disclosure effect for PE backed firms in the post-financing years remains high and significant $\left(\beta_{4}=1.60\right)$. With respect to the control variables, all coefficients and significance levels are similar to those of the first model.

Results of both models provide clear evidence in line with our expectations. PE backed firms switch to a higher disclosure policy in the pre-financing year and we interpret this behavior as an attempt to reduce information asymmetries inherent to this PE application. Moreover, we find multivariate evidence that the likelihood to provide complete financial statements is even higher from the moment PE investors have invested in the portfolio firm. This finding is a clear indication that the intensified corporate governance and increased professionalization resulting from the PE investors' presence has a complementary effect on the supply of the accounting disclosure of their portfolio firms.

In a third model, we sort out differences in disclosure policy by conditioning the data on investor type (government versus non-government PE backed) after controlling for intrinsic company characteristics. To retrieve potential differences between firms backed by different investor types, we extend model (1) by adding two dummy variables. Both interaction variables control for government relations. The first dummy is activated when a firm is backed by a government-related PE provider, both in the pre- and post-financing period (= Government_PE). The second dummy is activated from the moment a firm receives government-related PE onwards (= Government_PE $E_{\text {post }}$ ), and is zero otherwise. Incorporating 
these additional dummies allows to disentangle the incremental effects of investor types (government versus non-government related) on their portfolio firm's disclosure policy, conditioning for different subperiods. Again, we incorporate the same control variables as above:

$$
\begin{aligned}
\text {HIGHDISC }_{i t}= & \alpha+\beta_{1 i t} . P E+\beta_{2 i t} . P E_{\text {post }}+\beta_{3 i t} . \text { Government_PE }+\beta_{4 i t} \cdot \text { Government_PE } E_{\text {post }}+ \\
& \gamma_{i t} . \text { CONTROL VARIABLES }+U_{i t}
\end{aligned}
$$

Column 3 of Table 5 shows a significantly positive effect on disclosure in the pre-PE financing period within the government PE backed firms $\left(\beta_{3}=2.75\right)$ which is not present in the non-government PE backed sample. Although this shows that government PE backed firms disclose more in the pre-financing years compared to non-government PE backed firms, the difference in disclosure post PE financing date between both samples is not significantly different from zero. The combined effect of $\left(\beta_{3}+\beta_{4}\right)$ shows that, after the PE financing date, the total difference in disclosure extent between government and non-government PE backed firms is not significantly different from zero. This suggests that investor type has no overall impact on their portfolio companies' disclosure policy ex post. Hence, these multivariate findings do not corroborate our postulation that a PE portfolio firm's disclosure policy is related to the characteristics of the investor type. By contrast, it suggests that entrepreneurs trace different PE investor parties and do not adjust their disclosure policy in function of the investor type. As such, we find that for this sample of unlisted PE backed firms, the welldocumented difference in governance and professionalization between PE investors has no sizeable effects on the way financial statement disclosure of their portfolio companies is enforced.

\section{Sensitivity Analyses}

In subsequent sensitivity analyses, we additionally control for elements which could at least partially - drive our results. Since both the number of observations and some characteristics of PE backed and control firms differ after selection of firm-years where firms are free to report an abbreviated financial statement could make us concerned about the comparability of these samples. We therefore dealt with this matching issue in more detail and identified a perfect match sample where firm-year observations were only included in the analysis if each firm has a matched observation available for the same firm-year of the control 
sample. This more stringent matching method has the advantage that there is a matched equivalent available for each PE backed firm in the control sample and gives more confidence about the comparability of the observations across both samples over different firm-years. The analyses were rerun for this perfect matched sample and all patterns and results remain qualitatively equal. ${ }^{15}$

Additionally, we controlled for the inevitable endogeneity problem that is encountered when comparing PE backed firms with a set of matched firms. Although PE backed firms and their counterparts are matched as closely as possible in the pre-financing year (or the financing year if the company receives PE in the start up year), PE backed firms could still differ substantially from the matched firms due to intrinsic characteristics that are not controlled for in the analysis which might drive our findings. This endogeneity problem is often encountered in disclosure studies and is typically addressed by running two-stage equation models which take into account this kind of self-selection. We run two yearly logits for both the pre-financing and the financing year in which we specify the disclosure policy as a function of being PE backed and the same firm-specific characteristics used in the pooled panel logits. Focusing on these two years is important because these are the years where matching took place, which make them prone to potential uncontrolled selection bias.

In a next step, we estimate two-stage Heckman corrected logit models for these firmyears and compare the regression coefficients. In the two-stage logits, we first model the decision to attract PE as a function of a company's (asset and gross margin) growth, investment intensity, profitability and the total amount of free cash available. All the aforementioned variables could differ potentially between the both samples and as such might disturb the findings when we do not control for them. In a second step, these intrinsic differences between PE backed and non-PE backed firms are integrated in our initial estimation model to capture the effect of being PE backed. Results are discussed in more detail in Appendix 1 and show that controlling for the aforementioned firm characteristics which are not captured by the matching criteria, does not yield different results than for the uncontrolled yearly logits. These findings comfort us that our results are not substantially biased by the endogeneity present in our sample.

\section{CONCLUSION AND DISCUSSION}

Analytical disclosure studies present several arguments why a firm's disclosure policy and its corporate governance system in-place are thought to be related. Empirical studies, 
however, often show mixed results most likely since both corporate governance and disclosure are measured by noisy proxies. The current study tries to overcome these shortcomings by studying corporate disclosure policies in a specific setting, namely around the private equity (PE) financing event. Studying a firm's disclosure policy in relation to PE financing has the advantage that we do not have to rely on noisy proxies for changes in corporate governance structure since the analyzed firms experience an indisputable and perfectly identifiable change in their corporate environment. As such, this study not only complements accounting research by analyzing determinants of a firm's disclosure policy in relation with a changing corporate governance system in-place but also entrepreneurial finance research since this often treats the corporate reporting environment as exogenous.

More specifically, this study analyzes the disclosure policy of companies financed by PE investors, both before and after the PE investment, and compares it with the disclosure policy of matched non-PE backed firms. The disclosure policy is defined as the choice whether or not to disclose complete financial statements (which contain more details on sales levels and costs structures, amongst others) rather than abbreviated financial statements when possible. Reporting complete financial statements burdens a company with substantial proprietary costs inherent to the increased disclosure, making this a suitable proxy to measure unlisted firms' disclosure behavior. Analyses are run on a unique hand-collected sample of Belgian unlisted, PE backed firms in the years around the PE financing event. The specific legal environment and PE industry characteristics in Belgium make it particularly suitable to conduct this study. All Belgian firms, both listed and unlisted, have to report financial statements. This creates a possibility to study the impact of changes in ownership structure, corporate governance and professionalization patterns resulting from the PE investment on a firm's disclosure policy even when this firm is not listed on a stock exchange. Moreover, since about half of all PE investments come from public PE investment funds, these data shed more light on the impact of investor type on disclosure policies of portfolio firms. Studying the disclosure behavior longitudinally overcomes the often ignored feature that disclosure depends on a firm's changing environment or economics.

We find clear evidence that firms switch to a higher disclosure policy one year before they receive PE. This increase in disclosure is interpreted as an entrepreneurial attempt to reduce the information asymmetries inherent to the PE application. The commitment to this high disclosure is further intensified from the PE investment date onwards, suggesting a governance and professionalization impact of PE investors on their portfolio firm's financial 
reporting behavior. Conditioning the sample on differences in investor type shows that, after the PE financing date, portfolio firms' disclosure behavior does not differ systematically between government PE backed and non-government PE backed firms. However, government PE backed firms do show an earlier switch to a higher disclosure level. This finding might be attributed to a longer search-for-equity period for these firms. Firms that receive governmentrelated PE financing could initially have tried to attract non-government PE investors hereby providing more financial disclosure, but in the end failed to do so. In a later stage, these firms might have to resort to lower quality PE investors, typically being the government-related instances. However, the rather low number of observations prior to the PE finance for the non-government backed firms makes it hard to provide sound proof for this argument and needs to be corroborated by further research. Our results are robust for a number of additional sensitivity checks, including the endogeneity problem present in our sample. In general, the evidence is consistent with the conjecture that there exists a clear link between a firm's disclosure behavior and its changing corporate environment caused by the PE investment.

Our findings might, nevertheless, be subject to some caveats. We do not have specific information on the (stipulations in) contracts between the firms and their PE investors nor with other external parties like banks and creditors. As such, existing (debt) contracts could contain explicit stipulations about financial reporting policies, making the analyzed disclosure behavior less discretionary than a priori assumed. By dissecting these contracts, one could discern more precisely to what extent the increased disclosure is a consequence of the increased monitoring or rather a pure professionalization outcome. Additionally, the dataset contains only firms that applied for and actually received PE financing. As such, potential control sample firms could be PE applicants that were unable to attract it. We do not see this as a big issue since it could only underestimate our results making the current relations even stronger than they are now. We encourage other researchers to examine other institutional settings and to relate the disclosure behavior to contractual stipulations. This could shed more light on the interrelationship between PE monitoring and professionalization impulses on a portfolio firm's disclosure policy.

These results have important implications for several economic parties. Entrepreneurs can learn from this that financial disclosure is an important issue in PE screening and governance. Increased governance resulting from PE investor involvement and synergies coming from PE in-house skills make portfolio firms more likely to commit to a high disclosure strategy. Further, these results are also important for other stakeholders of PE 
backed companies like banks, competitors, employees or suppliers that actively make use of PE firm financial statements. PE investors affect the professionalization of their portfolio firms' financial reporting in that they contribute to a higher disclosure, making financial statements substantially more informative for external stakeholders. 


\section{APPENDIX 1}

Year-Logits and Two-Stage Treatment Logits in Pre-Financing and Financing Year

\begin{tabular}{|c|c|c|c|c|c|c|c|c|}
\hline \multirow{2}{*}{$\begin{array}{l}\text { Dependent }= \\
\text { Disclosure } \quad(1, \\
\text { al }\end{array}$} & \multicolumn{4}{|c|}{ Year $_{-1}$} & \multicolumn{4}{|c|}{ Year $_{0}$} \\
\hline & \multicolumn{2}{|c|}{ Test Logit } & \multicolumn{2}{|c|}{ Treatment Logit } & \multicolumn{2}{|c|}{ Test Logit } & \multicolumn{2}{|c|}{ Treatment Logit } \\
\hline Variable & Coeff & $z$ & Coeff & $z$ & Coeff & $z$ & Coeff & $z$ \\
\hline $\mathrm{PE}$ & 0.574 & $2.00^{\dagger}$ & - & - & 0.684 & $2.59^{\dagger}$ & - & - \\
\hline LNAGE & 0.040 & 0.20 & 0.058 & 0.57 & -0.195 & -1.18 & 0.213 & 1.53 \\
\hline FIXASSETS & -0.501 & -0.90 & -0.287 & -0.86 & 0.545 & 1.14 & 0.668 & 1.46 \\
\hline LEVERAGE & -0.994 & $-1.81^{*}$ & -1.019 & $-1.85^{*}$ & -1.025 & $-2.09^{\dagger}$ & -0.659 & $-1.87^{*}$ \\
\hline XORDINC & -0.114 & -0.28 & -0.126 & -0.68 & -0.691 & -1.40 & -0.824 & -1.20 \\
\hline LOSS & 0.149 & 0.49 & 0.002 & 0.02 & -0.079 & -0.29 & 0.028 & 0.13 \\
\hline Constant & -1.194 & $-1.73^{*}$ & -0.907 & $-2.49^{\dagger}$ & -1.131 & $-2.05^{\dagger}$ & -0.765 & -1.09 \\
\hline \multicolumn{3}{|c|}{$\rho$ (Test, Treatment) } & \multicolumn{2}{|r|}{-0.909} & \multicolumn{4}{|r|}{-0.06} \\
\hline \multicolumn{3}{|l|}{ Wald test of $\rho=0$} & \multicolumn{2}{|r|}{2.47} & \multicolumn{4}{|r|}{0.04} \\
\hline \multicolumn{3}{|c|}{ No. of observations } & \multicolumn{2}{|r|}{360} & \multirow{2}{*}{\multicolumn{2}{|c|}{442}} & & 416 \\
\hline \multicolumn{3}{|c|}{ Dependent $=P E(1,0)$} & \multicolumn{2}{|c|}{$\begin{array}{c}\text { Selection Logit } \\
(\text { Year }-1)\end{array}$} & & & \multicolumn{2}{|c|}{$\begin{array}{c}\text { Selection Logit } \\
\text { (Year0) }\end{array}$} \\
\hline \multirow{2}{*}{\multicolumn{3}{|c|}{$\Delta$ (Total Assets) }} & Coeff & $z$ & & & Coeff & $\bar{z}$ \\
\hline & & & -0.000 & -0.01 & & & 0.458 & $3.70^{\ddagger}$ \\
\hline \multicolumn{3}{|l|}{ Investments/TA } & 0.005 & 0.01 & & & 0.907 & $1.78^{\dagger}$ \\
\hline \multicolumn{3}{|c|}{$\Delta($ Gross Margin $)$} & -0.033 & -1.45 & & & 0.030 & $2.84^{*}$ \\
\hline \multicolumn{3}{|c|}{ Accumulated Profit/TA } & -1.863 & $-3.26^{\frac{1}{*}}$ & & & -2.384 & $-2.38^{\dagger}$ \\
\hline \multicolumn{3}{|c|}{ Cash Reserves/TA } & -1.954 & $-2.08^{\dagger}$ & & & -1.794 & $-2.47^{\dagger}$ \\
\hline \multicolumn{3}{|l|}{ Constant } & 0.103 & 1.14 & & & -0.265 & $-2.68^{+}$ \\
\hline
\end{tabular}

This table presents the results of two yearly cross-sectional logits, one in the prefinancing year $(\mathrm{t}-1)$ and one in the year of PE financing $(\mathrm{t} 0)$. The dependent variable is a dummy variable taking the value of one if a firm discloses a complete financial statement and zero otherwise. These yearly cross-sectional logit regressions show the relations between the decision to disclose complete financial statements and the propensity of being PE backed together with firm-specific variables in both matching years. Although PE backed firms and their counterparts are matched as closely as possible by size, age and sector industry in the pre-financing year (or the financing year if the company receives PE in the start up year), PE backed firms could still differ substantially from the matched firms due to intrinsic characteristics that are not controlled for in the uni- and multivariate analyses and might drive our findings. 
We address this potential endogeneity problem by additionally running two-equation models which take into account this kind of self-selection. If the correlation between the error terms of the uncorrected logit (Test Logit) and the two-stage logit (Treatment Logit) is low, we can be confident that our uncorrected model is not harmed by potential endogeneity present in the sample. In this two-step Treatment Logit, we first model the PE application as a function of a firm's $(i) \Delta$ (Total Assets): (year-on-year asset growth, relative to last year's assets), (ii) Investments intensity (investment in tangible and intangible assets as a percentage of total assets), $\Delta$ (Gross margin) (= year-on-year change in gross margin, being a proxy for sales levels, as a fraction of last year's gross margin figure), Accumulated profits (profits accumulated into retained earnings, expressed as a fraction of last year's assets) and the extent of Cash reserves (year-end cash situation as a percentage of last year's total assets). These specific variables are used in our selection model, since anecdotal and empirical evidence shows that these variables well capture uncontrolled differences in PE backed and non-PE backed firms. Robbie and Wright (1998) and Gompers and Lerner (2001), amongst others, report that PE backed firms typically have a higher growth pattern and investment (needs), are less profitable and are most often cash constrained.

In a second step, these intrinsic differences between PE backed and non-PE backed firms are integrated in our initial estimation model to capture the effect of being PE backed. Wald $\chi^{2}$ statistics indicate that both in the pre-financing year and the financing year itself the error terms between the uncorrected (Test) Logit and the Treatment Logit, controlling for endogeneity, are unrelated. This evidence suggests that although self-selection is present in our sample, it is not driving our results substantially. The coefficients of most control variables, however, are rather insignificant. We are not concerned about this finding since we loose a substantial amount of information by running these logits on a yearly basis instead of using the entire panel. The main reason for running these logits is to control for self-selection bias. Note that the number of observations in the Treatment Logits are lower than in the Test Logits due to missing data with respect to the additional variables needed to calculate the Selection Logits. Note that ${ }^{*}=$ significant at the $10 \%$ confidence level, ${ }^{\dagger}=$ significant at the $5 \%$ confidence level, ${ }^{+}=$significant at the $1 \%$ confidence level. 


\section{REFERENCES}

Admati, A.R. and Pfleiderer, P., 1994, "Robust financial contracting and the role of venture capitalists", Journal of Finance, vol. 49, pp. 371-402.

Akerlof, George, A., 1970, "The market for Lemons: Quality uncertainty and the market mechanism", The Quarterly Journal of Economics, Vol. 84 No. 3, pp. 488-500.

Baltagi, Badi, H., 2001, "Econometric analysis of panel data", John Wiley and Sons, Ltd, The Atrium, England, Second Edition, 293 pp.

Berlin, M., 1998, "That thing venture capitalists do", Business Review - Federal Reserve Bank of Philadelphia, January-February, pp. 15-26.

Bhattacharya, S. and Ritter, J. R. 1983, "Innovation and communication: signalling with partial disclosure", Review of Economic Studies, vol. 50, pp. 331-346.

Botosan, C. A. 1997, "Disclosure level and the cost of equity capital", Accounting Review, vol. 72 , no. 3, pp. 323-349.

Botosan, C., Frost, C., 1998, "Regulation, disclosure and market liquidity", Working Paper, Washington University and Dartmouth College.

Chen, S., DeFond, M. L., and Park, C. W. 2002, "Voluntary disclosure of balance sheet information in quarterly earnings announcements", Journal of Accounting and Economics, vol. 33, pp. 229-251.

Diamond, D. and Verecchia, R., 1991, "Disclosure, liquidity and the cost of capital", Journal of Finance, vol. 46, pp. 1325-1360.

Eng, L. L. and Mak, Y. T. 2003, "Corporate governance and voluntary disclosure", Journal of Accounting and Public Policy, vol. 22, pp. 325-345.

EVCA Statistics, European Venture Capital and Private Equity Association Yearbooks, various years, Zaventem - Diegem.

Forker, J.J., 1992, "Corporate governance and disclosure quality", Accounting and Business Research, 22 (86), pp. 111-124. 
Fried, V. H. and Hisrich, R. D. 1994, "Toward a model of venture capital investment decision making", Financial Management, vol. 23, no. 3, pp. 28-37.

Gigler, F. 1994, "Self-enforcing voluntary disclosures", Journal of Accounting Research, vol. 32 , no. 2, pp. 224-240.

Gompers, P. A. 1995, "Optimal investment, monitoring, and the staging of venture capital", Journal of Finance, vol. 50, no. 5, pp. 1461-1489.

Gompers, P. A. and Lerner, J. 2001, "The venture capital revolution", Journal of Economic Perspectives, vol. 15, no. 2, pp. 145-168.

Greene, W. H., Econometric Analysis, Prentice-Hall, third edition, 1997, 1010 p.

Grosman, S., 1981, "The role of warranties and private disclosure about product quality", Journal of Law and Economics, 24, pp. 461-483.

Hall, J. and Hofer, C. W., 1993, "Venture capitalists' decision criteria in new venture evaluation", Journal of Business Venturing, Vol. 8, Issue 1, p. 25-42.

Hand, J., 2005. "The value relevance of financial statements in the venture capital market", Accounting Review, fortcoming, April 2005.

Hart, O. and Moore, J., 1998, "Default and renegotiation: a dynamic model of debt", Quarterly Journal of Economics, vol. 113, pp. 1-41.

Healy, P. and Palepu, K. 2001, "Information asymmetry, corporate disclosure, and the capital markets: a review of the empirical disclosure literature", Journal of Accounting and Economics, vol. 31, pp. 405-440.

Healy, P., Hutton A. and Palepu, K. 1999, "Stock performance and intermediation changes surrounding sustained increases in disclosure", Contemporary Accounting Research, pp. 485520 .

Hellmann, T. and Puri., M. 2002, "Venture capital and the professionalization of start-up firms: empirical evidence", Journal of Finance, vol. 57, pp. 169-197. 
Ho, S. S. M. and Wong, K. S. 2001, "A study of the relationship between corporate governance structures and the extent of voluntary disclosure", Journal of International Accounting Auditing and Taxation, vol. 10, pp. 139-156.

Jain, B. A. and Kini, O. 1995, "Venture capitalist participation and the post-issue operating performance of IPO firms", Managerial and Decision Economics, vol. 16, pp. 593-606.

Jensen, M. C. and Meckling, W. H. 1976, "Theory of the firm: managerial behavior, agency costs and ownership structure", Journal of Financial Economics, vol. 3, no. 4, pp. 305-360.

Jensen, M. C. 1986, "Agency costs of free cash flow, corporate finance, and takeovers", American Economic Review, vol. 76, pp. 323-329.

Kaplan, S. N. and Strömberg, P. 2002, "Financial contracting meets the real world: an empirical analysis of venture capital contracts", Review of Economic Studies, pp. 1-35.

Lang, M. H. and Lundholm, R. J. 2000, "Voluntary disclosure and equity offerings: reducing information asymmetry of hyping the stock?", Contemporary Accounting Research, vol. 17, no. $4,623-662$.

Leftwich, R.W., Watts, R.S. and Zimmerman, J.L. 1981, "Voluntary corporate disclosure: the case of interim reporting", Journal of Accounting Research, Vol. 19 Supplement 1981, pp. 5077.

Leland, H. E. and Pyle, D. H. 1977, "Informational asymmetries, financial structure, and financial intermediation", Journal of Finance, vol. 32, no. 2, pp. 371-387

Leleux, B. and Surlemont B., 2003, "Public versus private venture capital: seeding or crowding out? A pan-European analysis", Journal of Business Venturing, 18, pp. 81-104.

Lerner, J. 1995, "Venture capitalists and the oversight of private firms", Journal of Finance, vol. 50, no. 1, pp. 301-318.

Lerner, J. 1999, "The government as venture capitalist: the long-run impact of the SBIR program", Journal of Business, vol. 72, no. 3, pp. 285-319.

Leuz, C. and Verecchia, R. E. 2000, "The economic consequences of increased disclosure", Journal of Accounting Research, vol. vol 38, no. Supplement, pp. 91-124. 
MacMillan, I. C., Zemann, L., and Subbanarasimha, B. N. 1987, "Criteria distinguishing successful from unsuccessful ventures in the venture screening process", Journal of Business Venturing, vol. 2, pp. 123-137.

Manigart, S., Baeyens, K. and Van Hyfte, W. 2002, "The survival of venture capital backed companies", Venture Capital, vol. 4, no. 2, pp. 103-124.

Manigart, S., De Waele, K., Wright, M., Robbie, K., Desbrières, P., Sapienza, H. J., and Beekman, A. 2000, "Venture capitalists, investment appraisal and accounting information: a comparative study of the USA, UK, France; Belgium and Holland", European Financial Management, vol. 6, no. 3, pp. 389-403.

Marquardt, C, Wiedman, C., 1998, "Voluntary disclosure, information asymmetry and insider selling through secondary equity offerings", Contemporary Accounting Research, pp. 505537.

McKinsey, 2002, Global Investor Opinion Survey.

Megginson, W. L. and Weiss, K.A. 1991, "Venture capital certification in initial public offerings", Journal of Finance, Vol. 46, no. 3, pp. 879-903.

Mitchell, F., Reid, G.C. and Terry, N., 1995, "Post investment demand for accounting information by venture capitalists", Accounting and Business Research, Vol. 25, n 99, pp. 186-196.

Milgrom, P., 1981, "Good news and bad news: representation theorems and applications", Bell Journal of Economics, 12, 380-391.

Raffournier, B. 1995, "The determinants of voluntary financial disclosure by Swiss listed firms", European Accounting Review, vol. 4, no. 2, pp. 261-280.

Ruland, W., Tung, S., and George, N. E. 1990, "Factors associated with the disclosure of managers' forecasts", Accounting Review, vol. 65, no. 3, pp. 710-721.

Schrand, C., Verecchia, R.E., "Disclosure choice and the cost of capital: Evidence from underpricing in initial public offering", Working Paper, The Warton School, Pennsylvania, 2002. 
Sapienza, H., Manigart, S. and Vermeir, W., 1996, "Venture capitalist governance and value added in four countries", Journal of Business Venturing, Vol. 11, N 6, pp. 439-469.

Sengupta, P. 1998, "Corporate disclosure quality and the cost of debt", Accounting Review, vol. 73 , no. 4 , pp. $459-474$.

Verecchia, R. E. 1983, "Discretionary disclosure", Journal of Accounting and Economics, vol. 5, pp. 179-194.

Wright, M. and Robbie, K. 1998, "Venture capital and private equity: a review and synthesis", Journal of Business Finance and Accounting, vol. 25, no. 5-6, pp. 521-571. 


\title{
TABLE 1
}

\section{Breakdown of Available Observations (Panel A) and Descriptives of Variables of}

\section{Interest in the PE Financing Year (Panel B)}

\author{
Panel A (a)
}

\begin{tabular}{|c|c|c|c|c|}
\hline & & All & PE backed & Non-PE backed \\
\hline \multicolumn{2}{|c|}{$\begin{array}{l}\text { Number of firm-observations for which financial } \\
\text { statement data are available }\end{array}$} & 876 & 438 & 438 \\
\hline- & $\begin{array}{l}\text { Firm-observations with missing information on } \\
\text { one or more of the criteria }\end{array}$ & (131) & (102) & (29) \\
\hline \multirow{2}{*}{$=$} & & 745 & 336 & 409 \\
\hline & $\begin{array}{l}\text { Firm-observations which exceed regulatory } \\
\text { minima }\end{array}$ & $(302)$ & (146) & (156) \\
\hline$=$ & Firm-observations of interest & 443 & 190 & 253 \\
\hline \multicolumn{2}{|c|}{ Panel B $^{(\mathrm{b})}$} & & & \\
\hline
\end{tabular}

\begin{tabular}{|c|c|c|c|c|c|c|c|}
\hline & & Mean & Median & Minimum & Maximum & Stdev. & $\mathbf{N}$ \\
\hline \multicolumn{8}{|l|}{ Age } \\
\hline & All & 9.59 & 6.00 & 0.00 & 91.00 & 10.9 & 443 \\
\hline & PE & 9.90 & 6.00 & 0.00 & 71.00 & 10.8 & 190 \\
\hline & Non-PE & 9.36 & 5.00 & 0.00 & 91.00 & 11.0 & 253 \\
\hline
\end{tabular}

Total Assets (EUR)

$\begin{array}{rrrrrrr}\text { All } & 1,557,752 & 1,014,479 & 24,021 & 23,472,443 & 2,107,599 & 443 \\ \text { PE } & 1,884,893 & 1,346,062 & 26,549 & 18,089,262 & 2,054,792 & 190 \\ \text { Non-PE } & 1,312,073 & 797,201 & 24,021 & 23,472,443 & 2,117,349 & 253\end{array}$

Fixed Assets (\%)

$\begin{array}{rcccccc}\text { All } & 37.20^{\dagger} & 34.04^{\dagger} & 0.00 & 98.83 & 27.01 & 443 \\ \text { PE } & 40.23 & 39.79 & 0.00 & 97.46 & 25.52 & 190 \\ \text { Non-PE } & 34.97 & 27.23 & 0.00 & 98.83 & 28.01 & 253\end{array}$

Leverage (\%)

$\begin{array}{rrrrrrr}\text { All } & 67.64 & 71.70 & 0.51 & 263.42 & 28.01 & 443 \\ \text { PE } & 68.95 & 71.83 & 0.51 & 263.42 & 27.98 & 190 \\ \text { Non-PE } & 66.48 & 71.53 & 1.32 & 201.13 & 28.00 & 253\end{array}$

Return on Assets (\%)

$\begin{array}{rrrrrrr}\text { All } & -0.82 & 0.74 & -174.95 & 109.82 & 17.43 & 443 \\ \text { PE } & -4.28 & 0.19 & -174.95 & 109.82 & 22.33 & 190 \\ \text { Non-PE } & 1.78 & 1.52 & -63.28 & 54.21 & 11.87 & 253\end{array}$

$\begin{array}{llr}\text { Top } 3 \text { Sectors } & \text { (1) Computer Services: } & 22.3 \% \\ & \text { (2) Wholesale Distribution: } & 19.4 \% \\ & \text { (3) Construction Sector: } & 7.7 \%\end{array}$

\footnotetext{
(a) Panel A of Table 1 gives a breakdown of the number of available firm-observations both for the PE backed and non-PE backed matched sample in the PE financing year.

${ }^{\text {(b) }}$ Panel B provides descriptive statistics on some characteristics of our PE backed and matched sample firms, as well as differences in means (medians) between both samples. Age is the number of years since the firm has been set up. Total assets is the absolute amount of total assets outstanding at the fiscal year-end, expressed in Euro (EUR). Fixed Assets is the relative proportion of fixed assets to total assets. Leverage is the proportion of a firm's Total Liabilities to Total Assets. Return on Assets refers to the profitability of the sample firms and equals a firm's fiscal earnings divided by total assets. Top 3 sectors refer to the 2-digit activity codes that are represented most in our sample. Asterisks mean that the means (medians) of the two groups are significantly different using a two-tailed t-test (Mann-Whitney $U$ test), ${ }^{*}: \mathrm{p}<0.10,{ }^{\dagger}: \mathrm{p}<0.05,{ }^{\ddagger}: \mathrm{p}<0.01$.
} 


\section{TABLE 2}

\section{Definition, measurement and expected sign of variables of interest ${ }^{\text {(a) }}$}

\section{Expected}

Variable

Definition

\section{Measurement}

\section{Sign}

\begin{tabular}{|c|c|c|c|}
\hline HIGHDISC & Voluntary Disclosure Dummy & $\begin{array}{l}\text { Binary variable, taking the value of } 1 \\
\text { when a firm reports a complete } \\
\text { financial statement although legally an } \\
\text { abbreviated format is sufficient }\end{array}$ & l \\
\hline PE & Private Equity Dummy & $\begin{array}{l}\text { Dummy variable, taking the value of } 1 \\
\text { when a firm is PE backed; this } \\
\text { dummy is activated both in the pre- } \\
\text { and post-investment years }\end{array}$ & + \\
\hline $\mathrm{PE}_{\text {post }}$ & $\begin{array}{l}\text { PE * Post-investment } \\
\text { dummy }\end{array}$ & $\begin{array}{l}\text { Dummy variable, taking the value of } 1 \\
\text { from the moment a firm is PE backed, } \\
0 \text { otherwise }\end{array}$ & + \\
\hline $\mathrm{PE}_{\text {year-3 }}$ & $\mathrm{PE} *$ Year-3 & $\begin{array}{l}\text { Dummy variable, activated three years } \\
\text { before the PE financing date }\end{array}$ & - \\
\hline $\mathrm{PE}_{\text {year-2 }}$ & $\mathrm{PE} *$ Year -2 & $\begin{array}{l}\text { Dummy variable, activated two years } \\
\text { before the PE financing date }\end{array}$ & - \\
\hline GOVERNMENT & Government dummy & $\begin{array}{l}\text { Interaction variable; captures } \\
\text { the effect of investor type on a } \\
\text { firm's disclosure policy. } 1= \\
\text { Government Backed, } 0=\text { Non- } \\
\text { Government Backed }\end{array}$ & - \\
\hline LNAGE & Age variable & $\begin{array}{l}\text { Natural logarithm of the } \\
\text { number of years since } \\
\text { foundation }\end{array}$ & - \\
\hline LEVERAGE & Leverage & $\begin{array}{l}\text { (Total Liabilities/Total Assets): } \\
\text { controls for a firm's debt obligation }\end{array}$ & - \\
\hline FIXASSETS & Fixed Assets in Place & $\begin{array}{l}\text { Firms' fixed assets as a } \\
\text { proportion of total assets }\end{array}$ & - \\
\hline XORDINC & $\begin{array}{l}\text { Extra-ordinary items } \\
\text { dummy }\end{array}$ & $\begin{array}{l}\text { Dummy variable taking the } \\
\text { value of } 1 \text { when extra-ordinary } \\
\text { income exceeds } 25 \% \text { of current } \\
\text { profit }\end{array}$ & + \\
\hline LOSS & Loss Dummy & $\begin{array}{l}\text { Binary variable taking the value } \\
\text { of } 1 \text { when a firm reports a loss } \\
\text { before taxes, zero otherwise }\end{array}$ & + \\
\hline
\end{tabular}

\footnotetext{
(a) This table gives an overview of all variables of interest analyzed in the univariate and multivariate analyses. The dependent variable HIGHDISC is analyzed as a function of pre- and post-PE financing variables to capture the willingness of firms that apply for and receive PE financing to disclose a complete financial statement, both in the pre- and post-PE financing years. Additionally, GOVERNMENT is a dummy variable which is activated if the PE investor is a government-related firm. LNAGE is the natural logarithm of a firm's age and controls for uncertainty and information-asymmetry problems. LEVERAGE measures the amount of a firm's Total Liabilities to Total Assets. FIXASSETS is the proportion of Fixed Assets to Total Assets and is expected to be negatively related to a firm's disclosure behavior. Further, XORDINC (a dummy variable activated when a firm reports an extraordinary income above $25 \%$ of its current profit) and LOSS (a dummy variable activated when a firm reports a loss) are two additional controls for the inherent risks of a firm.
} 
TABLE 3

\section{Evolution of High Disclosure Firms Per Subsample:}

([1] Non-PE Backed versus PE Backed and [2] Government versus Non-Government PE Backed) ${ }^{(a)}$

\begin{tabular}{|c|c|c|c|c|c|c|c|c|c|c|c|}
\hline & \multicolumn{3}{|c|}{ NON-PE BACKED } & \multicolumn{3}{|c|}{ PE BACKED } & \multicolumn{3}{|c|}{ GOVERNMENT PE BACKED } & $\chi^{2}$ & $\chi^{2}$ \\
\hline Year & $N$ & $N$ & $\%$ & $N$ & $N$ & $\%$ & $N$ & $N$ & $\%$ & PEversus & $\overline{G o v P E \text { versus }}$ \\
\hline & all & Highdisc & Highdisc & all & Highdisc & Highdisc & all & Highdisc & Highdisc & nonPE & Non-GovPE \\
\hline-3 & 128 & 20 & $15.6 \%$ & 115 & 18 & $15.7 \%$ & 78 & 14 & $17.9 \%$ & 0.00 & $\overline{0.72}$ \\
\hline-2 & 146 & 20 & $13.7 \%$ & 143 & 24 & $16.8 \%$ & 94 & 19 & $20.2 \%$ & 0.39 & 1.69 \\
\hline-1 & 202 & 27 & $13.4 \%$ & 174 & 35 & $20.1 \%$ & 122 & 23 & $18.9 \%$ & $2.21^{*}$ & 0.26 \\
\hline 0 & 253 & 33 & $13.0 \%$ & 190 & 45 & $23.4 \%$ & 134 & 28 & $20.9 \%$ & 5.87 & 0.48 \\
\hline 1 & 281 & 42 & $14.9 \%$ & 218 & 66 & $30.3 \%$ & 154 & 44 & $28.6 \%$ & $10.83^{*}$ & 0.38 \\
\hline 2 & 285 & 42 & $14.7 \%$ & 234 & 76 & $32.5 \%$ & 173 & 56 & $32.4 \%$ & $14.37^{\prime}$ & 0.00 \\
\hline 3 & 258 & 43 & $16.7 \%$ & 212 & 70 & $33.0 \%$ & 158 & 51 & $32.3 \%$ & $10.35^{t}$ & 0.07 \\
\hline 4 & 206 & 33 & $16.0 \%$ & 161 & 54 & $33.5 \%$ & 116 & 41 & $35.3 \%$ & 9.34 & 0.31 \\
\hline 5 & 16 & 27 & $16.3 \%$ & 123 & 45 & $36.6 \%$ & 87 & 34 & $39.1 \%$ & $9.07^{*}$ & 0.38 \\
\hline Sum & 1,924 & 287 & & 1,570 & 433 & & 1,116 & 310 & & & \\
\hline Mean $(t-3 ; t+5)$ & 214 & 32 & $14.9 \%$ & 174 & 48 & $27.6 \%$ & 124 & 34 & $27.8 \%$ & & \\
\hline $\operatorname{Mean}(t-3 ; t-1)$ & 159 & 22 & $14.1 \%$ & 144 & 26 & $17.8 \%$ & 98 & 19 & $19.0 \%$ & & \\
\hline Mean $(t 0 ; t+5)$ & 241 & 37 & $15.2 \%$ & 190 & 59 & $31.3 \%$ & 137 & 42 & $30.9 \%$ & & \\
\hline
\end{tabular}

(a) Table 3 reports descriptive evolutions (total number as well as relative percentage) of the total number of firm-year observations for respectively the non-PE backed, PE backed subsample and the government-PE backed subsample. In order to test our hypotheses we focus on those firm-years in which firms comply with the regulatory minima to report an abbreviated financial statement. This additional condition yields an unequal number of firm-year observations across both samples. The focus of our analyses is, however, on those firms that meet the minimum requirements and hence have the choice to report a standard (abbreviated) format or a more detailed (complete) financial statement. Imposing this condition on our data leads to an unequal number of firm-year observations in both samples across years since a specific firm might fulfill the requirements to report an abbreviated format in one year although its matched firm does not (or: no longer) meet these minimum requirements. Further, unequal number of observations in the PE backed and non-PE backed sample are also a result of missing data on one or more elements of the financial statement items to calculate the compliance with the minimum criteria. A breakdown of a perfect match sample (i.e. sample for which a firm-year observation in one subsample was only incorporated in the analysis if its matching firm-year observation was also available - available on request) shows a similar pattern. We expect a high and surging number of PE backed firms compared to a rather stable number of non-PE backed firms that report complete financial statements around the PE financing event, since no specific event is taking place for the latter firms. Comparing non-government PE backed firms with government PE backed firms, indicates differences within the PE backed sample, dependent on investor type. For each (sub)sample, the number of firms that report complete financial statements (i.e. commit to a higher level of disclosure than legally required) is shown as a fraction of the total number of available observations. $\chi^{2}$ test-statistics show differences in high disclosure patterns between (1) the PE backed and non-PE backed subsample and (2) within the PE backed sample, dependent on investor type (i.e. Government PE backed versus Non-Government-PE backed). Nall $=$ Total number of observations and NHighdisc $=$ number of high disclosure firms. Note that: $*=$ significant at the $10 \%$ confidence level, $\uparrow=$ significant at the $5 \%$ confidence level, $\neq=$ significant at the $1 \%$ confidence level. 
TABLE 4

Descriptive Statistics for Regression Variables Including Differences in Means and Medians for High Disclosure Firms and Low Disclosure Firms ${ }^{\text {(a) }}$

\begin{tabular}{|c|c|c|c|}
\hline \multicolumn{4}{|c|}{ Panel A: Dummy variables } \\
\hline Variable & Sample & $\mathrm{N}_{\text {HIGHDISC }}$ & $\mathrm{N}_{\text {LOWDISC }}$ \\
\hline \multirow{2}{*}{$\mathrm{PE}$} & 1 & $433^{\ddagger}(27.58 \%)$ & $1,137 \quad(72.42 \%)$ \\
\hline & 0 & $287 \quad(14.92 \%)$ & $1,637 \quad(85.08 \%)$ \\
\hline XORD & 1 & $78^{*}(15.18 \%)$ & $436 \quad(84.82 \%)$ \\
\hline INC & 0 & $642(21.54 \%)$ & $2,338 \quad(78.46 \%)$ \\
\hline \multirow{2}{*}{ LOSS } & 1 & $266 \quad(21.61 \%)$ & $965 \quad(78.39 \%)$ \\
\hline & 0 & $454 \quad(20.06 \%)$ & $1,809 \quad(79.94 \%)$ \\
\hline
\end{tabular}

Panel B: Continuous Variables

\begin{tabular}{lrrrrrrrr}
\multicolumn{1}{c}{ Variable } & Sample & $\mathrm{N}$ & Mean & Median & Minimum & Maximum & Stddev & Skewness \\
\hline \multirow{2}{*}{ LNAGE } & HIGHDISC & 720 & $1.875^{\dagger}$ & $1.792^{\dagger}$ & 0.000 & 4.317 & 0.916 & 0.202 \\
& LOWDISC & 2774 & 1.939 & 1.946 & 0.000 & 4.554 & 0.863 & 0.092 \\
LEVERAGE & HIGHDISC & 720 & $0.579^{\ddagger}$ & $0.610^{\ddagger}$ & 0.005 & 2.634 & 0.337 & 0.517 \\
\multirow{2}{*}{ FIX } & LOWDISC & 2774 & 0.689 & 0.725 & 0.003 & 2.425 & 0.281 & 0.419 \\
ASSETS & HIGHDISC & 720 & 0.392 & 0.330 & 0.000 & 0.990 & 0.319 & 0.412 \\
& LOWDISC & 2774 & 0.369 & 0.325 & 0.000 & 0.991 & 0.267 & 0.589
\end{tabular}


TABLE 4 - CONTINUED

\begin{tabular}{rrrrr}
\hline Panel C: Correlations & & & & \\
& & & & \\
Variable & HIGHDISC & LNAGE & LEVERAGE & FIXEDASSETS \\
\hline HIGHDISC & 1.000 & -0.029 & -0.149 & 0.033 \\
& - & $(0.077)$ & $(<0.001)$ & $(0.048)$ \\
LNAGE & -0.033 & 1.000 & -0.108 & -0.018 \\
& $(0.052)$ & - & $(<0.001)$ & $(0.286)$ \\
LEVERAGE & -0.149 & -0.110 & 1.000 & -0.120 \\
& $(<0.001)$ & $(0.077)$ & - & $(<0.001)$ \\
FIXASSETS & 0.002 & -0.002 & -0.091 & 1.000 \\
& $(0.906)$ & $(0.919)$ & $(<0.001)$ & - \\
\hline \hline
\end{tabular}

(a) Panel A reports univariate proportionate differences in disclosure tendency ( $\chi^{2}$ test results) in relation to (1) receiving PE financing (PE), (2) reporting extraordinary income above $25 \%$ of current income (XORDINC) and (3) reporting a loss before taxes (LOSS). Panel B provides descriptive statistics for the continuous dependent variables for both the subsample of high disclosure firms (HIGHDISC) and low disclosure firms (LOWDISC). Two-tailed t-test statistics (Mann Whitney U test statistics) have been run to control for differences in means (medians) for both subsamples (HIGHDISC - i.e. firms that report a complete financial statement although legally an abbreviated format is sufficient - versus LOWDISC - i.e. firms that follow minima legal requirements and hence report an abbreviated financial statement). In Panel C, we provide Pearson (above the diagonal line) and Spearman (under the diagonal line) correlations for the variable of interest, HIGHDISC, and the continuous variables used in our multivariate analyses. Note that ${ }^{*}$ indicates significance at the $10 \%$ confidence level, ${ }^{\dagger}=$ at the $5 \%$ confidence level, $=$ at the $1 \%$ confidence level. 


\section{TABLE 5}

\section{Panel Logit Regressions (Random Effects Model) ${ }^{(a)}$}

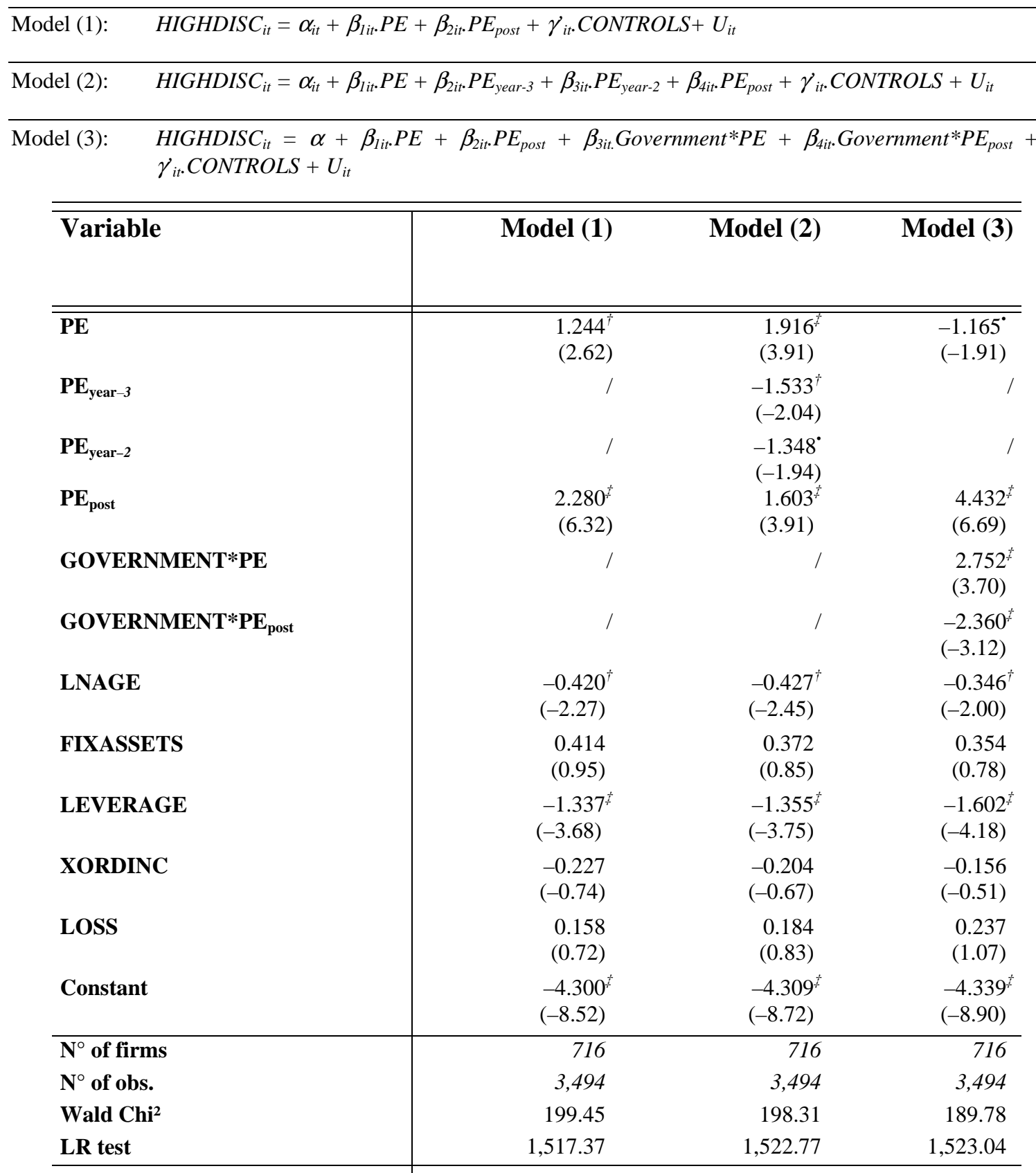

(a) This panel logit uses a random effects estimation method for three alternative model specifications. Panel logits techniques combine cross-sectional and time-series characteristics in one optimal model and meanwhile control for individual heterogeneity across firms, collinearity among the variables and firms dynamics over time. For more information on panel logit analyses, we refer to Greene (1997) and Baltagi (2001). We model the disclosure decision of sample and control firms as a function of variables related to receiving PE both in the pre- and post-investment years (Model 1 and 2) and additionally check for differences between investor types (Model 3). For a rigorous description of all variables of interest and control variables, we refer to Table 2 . Note that $*$ indicates significance at the $10 \%$ confidence level, $\dagger=$ at the $5 \%$ confidence level, $\ddagger=$ at the $1 \%$ confidence level. 


\section{FIGURE 1}

\section{Evolution of High Disclosure Firms Per Subsample (PE Backed versus Non-PE Backed)}

(a)

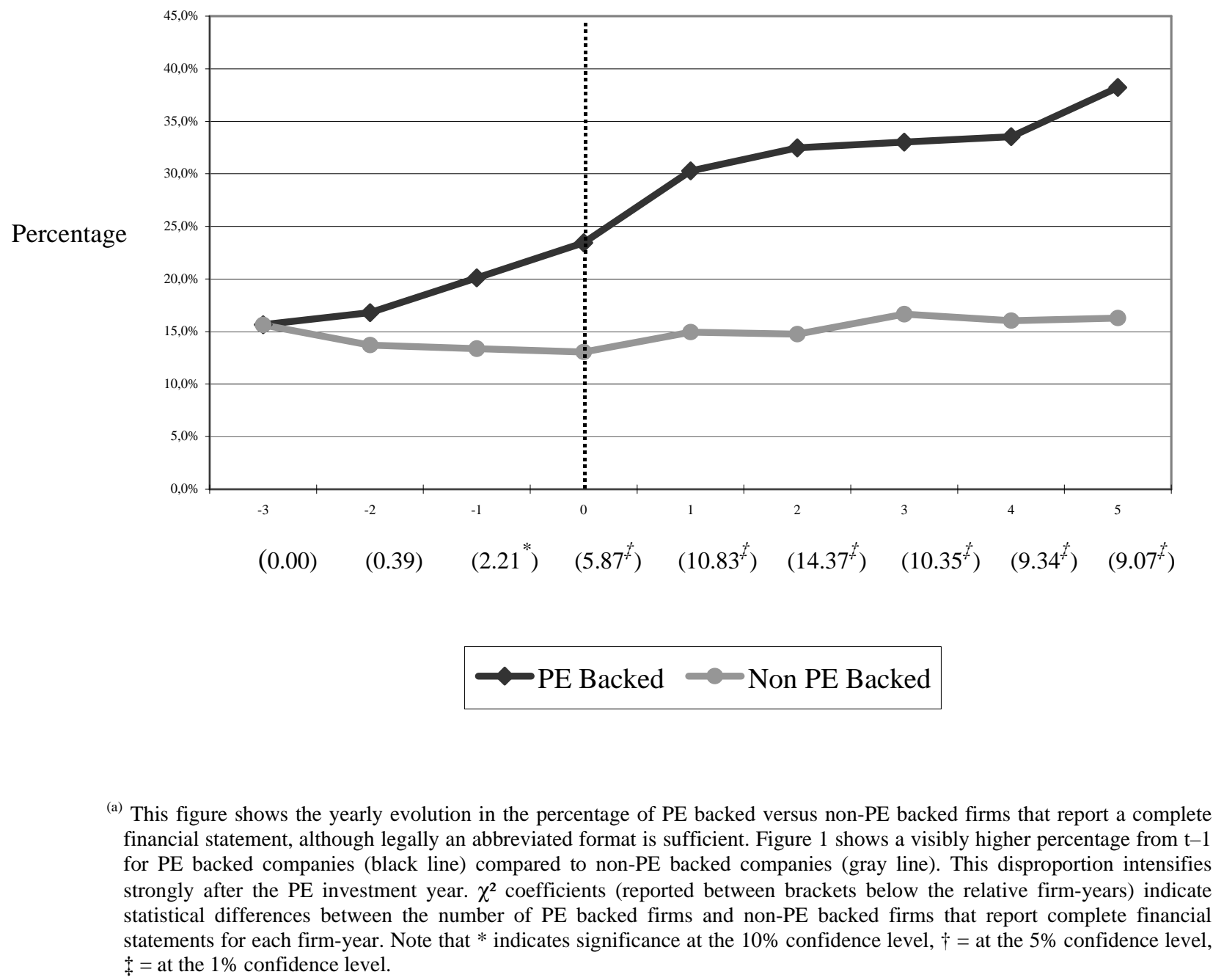
$\ddagger=$ at the $1 \%$ confidence level. 
${ }^{1}$ We use the term private equity (PE) rather than venture capital throughout this study, based on the characteristics of our sample. According to the European Venture Capital and Private Equity Association (EVCA) definition, 'venture capital' is defined as a "subset of private equity and refers to equity investments made for the launch, early development, or expansion of a business." Private equity is broader in meaning and is also used to define "external equity capital that is raised to strengthen a company's balance sheet, to make acquisitions or to finance a management buy-out or buy-in" (EVCA Glossary). Since a considerable number of our observations (cfr. infra) refer to later stage deals and hence do not satisfy the exact definition of venture capital, we use private equity to label all our equity financed deals.

${ }^{2}$ Recent studies acknowledge this shortage of attention and explicitly study earnings characteristics of unlisted firms in a regulatory setting where financial reporting requirements of unlisted firms are similar to those of listed firms (e.g. Ball and Shivakumar (2004), Hand (2005)). The importance and contribution to the economy of unlisted firms is high. In Europe, unlisted firms constitute over $99 \%$ of all private non- agricultural entities and hence are a non-negligible part of the economy. Figures for Belgium are similar to European averages in that about $99 \%$ of all Belgian firms are unlisted and they contribute to the large majority of total GDP.

3 This argumentation, however, implicitly assumes that entrepreneurs focus on one PE investment party at a time instead of 'go shopping' with several investment parties. Anecdotal evidence, however, shows that this is not always the case. Nevertheless, it still is relevant to study potential differences in disclosure behavior prior to the PE investment, dependent upon the specific investor's type that eventually takes up the investment.

${ }^{4}$ Our postulated relation is opposite to the one developed in Eng and Mak (2003), where the authors suggest and find a positive relation between government intervention and disclosure policy. The main reason why we expect this inverse relation is that we study unlisted firms with a rather small investor base, even after PE participation. Eng and Mak (2003) focus on a substantially different setting and study the disclosure behavior of listed firms leading to these different propositions.

5 This law is in accordance with the $4^{\text {th }}$ European Directive which defines a Small and Medium-sized Enterprise as a firm that does not exceed two or more of the following criteria: 250 employees, EUR 20 million sales and EUR 10 million total assets. Each European member State is allowed to adopt lower thresholds into their national legislation. Hence, Belgium applies more stringent rules to classify a firm as a large versus small entity. Belgian law also states that if firms belong to a group, the minimum criteria are calculated on a consolidated basis (Royal Decree of October 8, 1976, art. 12, §2). Portfolio companies of $\mathrm{PE}$ investment firms, however, are an important exception to this rule since their business areas are too divergent and therefore do not have to be consolidated. Consequently, portfolio companies of PE backed firms still have the possibility to report an abbreviated financial statement if their individual financial statement figures do not exceed the regulatory minima. Note that the aforementioned criteria and amounts are the current minima and evolved over our observation period. Up to 1991, e.g., annual turnover had to be lower than 145 million Belgian Francs (BEF) and total assets should not exceed 70 million BEF. Between 1991 and 1995, the maximum level for annual turnover was 170 million BEF and for total assets 85 million BEF. From 1996 on, turnover and total assets minima were respectively 200 million $\mathrm{BEF}$ and 100 million BEF. Also note that BEF is the former currency of Belgium (before January 1, 2002), with conversion rate: 1 Euro $=40.3399$ BEF. 
${ }^{6}$ To some extent, our study empirically tests an extension of the feedback effect equilibrium model, developed by Bhattacharya and Ritter (1983). These authors develop a model in which asymmetrically informed agents are motivated to communicate their private information to a subset of uninformed agents, but can only do this through channels which convey directly useful information to competitors. Their model is drawn in a setting where firms have high R\&D spending and need to raise financing but can only do this by reducing their informational advantage, i.e. by disclosing technological information publicly. In our setting, sample firms also have to decide on the amount of disclosed information which can be useful for competitors (e.g. sales levels, cost structures, etc.). However, the disclosure we measure is entirely financial and does not convey information on any technological advantage.

${ }^{7}$ From those firms that switch to a higher disclosure strategy, about $95 \%$ stick to this complete financial statement reporting strategy in later years. This finding confirms our argument that a switch to a complete financial reporting is not likely to be reversed in a later stage and is a suitable proxy for a firm's disclosure commitment.

${ }^{8}$ One can be doubtful that these matching criteria are sufficient to find a proper match for each PE backed firms and that they might be insufficient to make sure that a PE firm and its matched equivalent are indeed proper matches. One potential problem that might arise from this incomplete matching is that our multivariate panel regression results are impacted by a self-selection problem, as mentioned in Heckman (1979). In response to this problem, we run two-stage equation models to capture these treatment effects (Greene, 1997) of which the results are reported in the sensitivity analyses.

${ }^{9}$ Although we identified $556 \mathrm{PE}$ backed firms and an equal number of matched firms, the available number of observations is in each year is lower due to the unbalanced characteristics of the sample.

${ }^{10}$ Although the initial matching criteria worked well to identify a sample of non-PE backed firms that is comparable to the PE backed sample with respect to age, sector classification and size, the additional conditioning on complete financial statements and the fact that some firms have missing information with respect to the variables of interest causes these differences with respect to the average size in the samples of interest.

${ }^{11}$ In unreported analyses, we also created dummies which were respectively activated when a firm's extraordinary income is higher than $10 \%$ and $50 \%$ of current profit levels. All results remain stable with respect to these refinements.

${ }^{12}$ Often, disclosure studies also control for a firm's size and proxy this variable by (the natural logarithm of) a firm's market value or by (the natural logarithm of) total assets. However, we do not possess data on the individual firms' market value since we study data of unlisted firms. Moreover, controlling for size by looking at the firm's total assets is inappropriate in this setting given that total assets is one of the three identifiable elements which determine whether or not a firm is obliged to report a complete financial statement (see Section about the disclosure proxy (3.2)). As a consequence, we opt not to incorporate a size variable in our analyses.

${ }^{13}$ With respect to commitment to a higher disclosure policy, we already mentioned that of those firms that switch to a higher disclosure strategy in the pre-financing years, most firms stick to this high disclosure level. From the 43 firms that were identified reporting a complete financial statement from the pre-financing years onwards, only 3 reverse this high disclosure strategy in a later stage. This provides evidence that the analyzed disclosure strategy is to be interpreted as a persistent commitment to higher disclosure, and hence is expected to lead to higher economic benefits than an occasional switch. 
${ }^{14}$ This increase in probability is calculated as follows: the initial proportion between high disclosure firms (= firms that report a complete financial statement) and firms that follow the legal requirements $(=$ report an abbreviated format) is $(720 / 3,494)=0.206$. The logit coefficient on PE $\left(\beta_{1}\right)=1.244$ and corresponds to an odds ratio of $\mathrm{e}^{1.244}=3.469$. Multiplying the initial proportion 0.206 with this calculated odds ratio conducts a new odds of 0.715 . Since the odds is the probability divided by the non-probability, we obtain the following equation: $\mathrm{x} /(1-\mathrm{x})=0.715$ or $\mathrm{x}=0.417$. This means that for each PE backed observation the probability of being in the high disclosure sample $=41.7 \%$. This corresponds to an increase of $(41.7 \%-20.6 \%)=21.1 \%$. For the coefficient on $\mathrm{PE}_{\mathrm{post}}$, one can perform an identical calculation to estimate the increase in probability.

15 However, since the observations are matched in the (pre-)financing year, obtaining a perfectly matched observation per year is not necessarily our main concern. Differences in growth patterns and financial reporting policy are specific elements which make this dataset particularly attractive to analyze. Eliminating those firm-year observations for which no perfect match is available, inevitably also eliminates a substantial amount of useful information on sample and control firm characteristics and yields a substantially lower number of observations to be used in the analyses. For these reasons, we choose to report the results of the unconditioned samples in our main analyses. 